Article

\title{
Study of the Water Quality Index and Polycyclic Aromatic Hydrocarbon for a River Receiving Treated Landfill Leachate
}

\author{
Brenda Tan Pei Jian ${ }^{1}$, Muhammad Raza Ul Mustafa ${ }^{1, *}\left(\mathbb{0}\right.$, Mohamed Hasnain Isa ${ }^{2}$, Asim Yaqub ${ }^{3}$ \\ and Ho Yeek Chia ${ }^{1}$ (D) \\ 1 Department of Civil and Environmental Engineering, Universiti Teknologi PETRONAS, Seri Iskandar 32610, \\ Perak Darul Ridzuan, Malaysia; brenda_17007665@utp.edu.my (B.T.P.J.); yeekchia.ho@utp.edu.my (H.Y.C.) \\ 2 Civil Engineering Programme, Faculty of Engineering, Universiti Teknologi Brunei, Tungku Highway, \\ Gadong BE1410, Brunei; mohamed.isa@utb.edu.bn \\ 3 Department of Environmental Sciences, COMSATS University Islamabad Abbottabad Campus, \\ Abbottabad 22060, Pakistan; asimyaqub@ciit.net.pk \\ * Correspondence: raza.mustafa@utp.edu.my
}

Received: 29 July 2020; Accepted: 18 September 2020; Published: 16 October 2020

\begin{abstract}
Rising solid waste production has caused high levels of environmental pollution. Population growth, economic patterns, and lifestyle patterns are major factors that have led to the alarming rate of solid waste production. Generally, solid wastes such as paper, wood, and plastic are disposed into landfills due to its low operation and maintenance costs. However, leachate discharged from landfills could be a problem in surfaces and groundwater if not adequately treated. This study investigated the patterns of the water quality index (WQI) and polycyclic aromatic hydrocarbons $(\mathrm{PAH})$ along Johan River in Perak, Malaysia, which received treated leachate from a nearby landfill. An artificial neural network (ANN) was also applied to predict WQI and PAH concentration of the river. Seven sampling stations were chosen along the river. The stations represented the upstream of leachate discharge, point of leachate discharge, and five locations downstream of the landfill. Sampling was conducted for one year starting July 2018. Physicochemical parameters, namely $\mathrm{pH}$, biological oxygen demand, chemical oxygen demand, ammoniacal nitrogen, total suspended solids, and dissolved oxygen, were used to compute the water quality index (WQI). PAH concentrations were determined by liquid-liquid extraction of water samples followed by an analysis using gas chromatography. Results showed that WQI of Johan River was under Class III where intensive treatment was required to make it suitable for drinking purposes. The highest recorded PAH concentrations were fluoranthene (333.4 ppb) in the dry season and benzo(a) pyrene (93.5 ppb) in the wet season. A correlation coefficient (Rp) for a model prediction based on WQI-ANN and TEC-ANN (toxicity equivalent concentration) in the wet and dry seasons was $0.9915,0.9431,0.9999$, and 0.9999, respectively. ANN results showed good model performance with $\mathrm{Rp} \approx 0.9$. This study suggested that ANN is a useful tool for water quality studies.
\end{abstract}

Keywords: landfill; leachate; river; water quality index (WQI); polycyclic aromatic hydrocarbon (PAH); artificial neural network (ANN)

\section{Introduction}

Increasing municipal solid waste (MSW) generation is a major challenge in Malaysia, especially in rapidly growing towns and cities. MSW are wastes that originate from households, residential areas, industries, or any other commercial activities. These include glass, plastics, paper, metal, garden waste, and organic waste. Lifestyle, population, and social and economic conditions are the main factors 
that contribute to the average per capita generation of municipal waste in Malaysia [1]. Meanwhile, the Government of Malaysia data, based on the 9th Malaysian Plan (RMK9), showed that the amount of MSW is expected to double in line with the population growth by the year 2020. The average per capita generation of MSW rate was reported to have increased from $0.67 \mathrm{~kg} / \mathrm{capita} /$ day in 2001 to $0.8 \mathrm{~kg} / \mathrm{capita} /$ day in 2005 (RMK9). At present, landfilling is widely used for the disposal of solid wastes due to its low operation and maintenance costs. The Ministry of Housing and Local Government [2] reported that a total of 290 landfill sites were constructed by Malaysian Government; 176 of them are in operation and 114 have closed due to inadequate space and capacity. With the vast amount of MSW disposed, leachate production is expected to increase.

Leachate generated from landfills via precipitation, surface runoff, or water content of the waste [3] is highly contaminated and highly toxic due to high concentrations of micropollutants such as steroids, hormones, personal care products, heavy metals, pesticides, polycyclic aromatic hydrocarbons, and endocrine disrupting chemicals [4]. These pollutants are harmful, carcinogenic, and persistent in the environment [5]. The water quality index (WQI) is often used to determine the general impact of a waste stream on water bodies through the monitoring of several water quality parameters [6]. The Department of Environment in Malaysia has adopted National Water Quality Standards (NWQS) and classified uses of water based on WQI, as shown in Table 1.

Table 1. National water quality standards (NWQS) for Malaysia [7].

\begin{tabular}{ccc}
\hline Class & WQI & Possible Usage \\
\hline I & 93 and above & Safe for direct drinking \\
II & From 78 to $<93$ & Require treatment for drinking purposes \\
III & From 52 to $<78$ & Intensive treatment for drinking \\
IV & From 31 to $<52$ & Only suitable for plant and domestic animal uses \\
V & From 11 to $<31$ & Cannot be used for the purposes listed in Classes I-IV \\
\hline
\end{tabular}

WQI is the most common and universal method used for evaluating the quality of water bodies. WQI is based on several environmental parameters that are effectively represented as a single value to reflect the status of water; it is an effective approach in water quality assessment and management [8]. The inclusion of modelling tools, such as an artificial neural network to predict WQI of a river, are gaining popularity. It is noted that artificial neural networks (ANN) have sustained an incremental growth in many areas of research that have exceedingly been employed for water quality problems. Much research has focused on the Levenberg-Marquardt technique in predicting WQI. Researchers such as Binayini and Satapathy [9] concluded that ANN is a functional tool in evaluating water quality as it simplifies the traditional methods of calculating WQI, which saves substantial efforts and time through optimized calculations. PAHs have been identified as general causes of deterioration of aquatic ecosystems. Exposure of aquatic life to low levels of PAHs can affect feminization, fertility, and spawning period of male fish within several weeks $[10,11]$. Cancer in fish and especially in benthic organisms in natural aquatic systems has also been reported. Baali and Yahyaoui [12] reported that benzo [a] pyrene leads to a decrease in weight and growth, an increase in the gonado-somatic index (GSI) in Japanese medaka (Oryzias latipes), and teratogenic effects on the heart of sardines (Clupea pallasii), zebrafish, and anemia in scorpion fish (Sebastes schlegelii).

PAHs often accumulate in marine environments to harm aquatic organisms and human health. It is crucial to assess the risk posed by PAHs to protect human health and for ecological environment security. The toxic equivalency factor (TEF) approach was adopted to determine the overall hazard associated with a combination of PAHs relative to the reference PAH, i.e., benzo(a)pyrene. The toxicity equivalent concentration (TEC) is calculated by adding the weighted toxicities of all PAHs using Equation (1) [13].

$$
T E C=\sum_{i}^{n}\left(X_{i}\right)\left(T E F_{i}\right)
$$


where $X_{i}$ is concentration of individual PAH and $T E F_{i}$ is toxic equivalency factor of PAH relative to benzo [a] pyrene presented in Table $2[14,15]$.

Table 2. Toxic Equivalency Factor values of 16 priority polycyclic aromatic hydrocarbons.

\begin{tabular}{cc}
\hline Component & TEF \\
\hline Naphthalene & 0.001 \\
Acenaphthylene & 0.001 \\
Acenaphthene & 0.001 \\
Fluorene & 0.001 \\
Phenanthrene & 0.001 \\
Anthracene & 0.01 \\
Fluoranthene & 0.001 \\
Pyrene & 0.001 \\
Benzo (a) anthracene & 0.1 \\
Chrysene & 0.01 \\
Benzo (b) fluoranthene & 0.1 \\
Benzo (k) fluoranthene & 0.1 \\
Benzo (a) pyrene & 1 \\
Dibenzo (a,h) anthracene & 5 \\
Indeno $(1,2,3-c, d)$ pyrene & 0.1 \\
Benzo $(\mathrm{g}, \mathrm{h}, \mathrm{i})$ perylene & 0.01 \\
\hline &
\end{tabular}

The aims of this study are as follows: (i) to investigate the patterns of the water quality index and PAH along the Johan River, which have received treated landfill leachate, and (ii) to create an easy and practical method to simulate the status of Johan River. Currently, there is limited literature on river water quality with a focus on micropollutants (in this case PAH) prediction. Thus, this study provides a new direction for water quality studies.

\section{Study Area}

Perak is the second largest state among the 14 states in Malaysia; covering 21,006 km² of land area [16]. It is bordered by Penang, Kedah, Kelantan, Pahang, and Selangor. This study focused on Papan landfill in Perak, Malaysia (Figure 1). It is located in Ulu and accommodates up to 500 tons of waste daily. Papan landfill receives solid wastes from different areas such as the Ipoh, Batu Gajah, Kampar, and Central Perak districts due to its location and size. This landfill is regarded as a sanitary landfill (ranked Level 4). It is equipped with a three-layer membrane leachate collection system, leachate treatment plant, and methane gas facility. The landfill is estimated to have a life expectancy of 35 years [17]. Treated leachate is discharged into Johan River. 


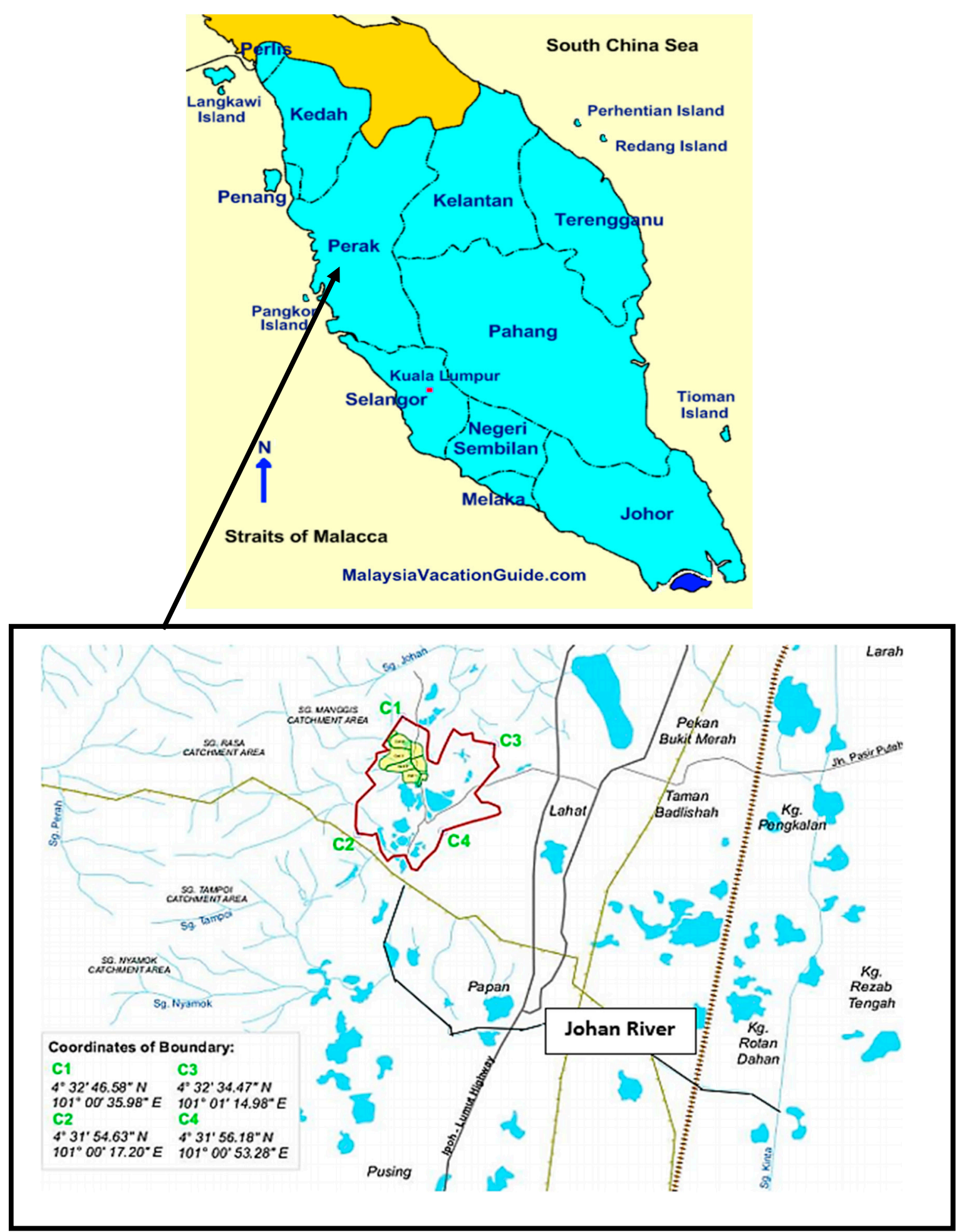

Figure 1. Papan landfill $[17,18]$.

\subsection{Sampling Locations}

Samples were collected every month for a year, from July 2018 to June 2019. This period was considered satisfactory as it covered all probable seasonal variations for the studied variables. Seven sampling points were selected in this study (Table 3). Three sampling stations (Up, DP, A) were located within Papan landfill premises and four stations (B, C, D, E) were located outside the landfill 
along Johan River. Sampling points (Figure 2) were chosen to cover the stretch of the river upstream and downstream of the landfill. Table 3 describes locations of the sampling stations.

Table 3. Location of sampling stations.

\begin{tabular}{ccc}
\hline Sampling Stations & Coordinates & Description \\
\hline UP & $4.54721,101.01769$ & Upstream of leachate discharge \\
DP & $4.53752,101.01315$ & Point of treated leachate discharge \\
A & $4.53624,101.01386$ & $150 \mathrm{~m}$ downstream of discharge point \\
B & $4.52388,101.01$ & $2 \mathrm{~km}$ downstream of discharge point \\
C & $4.50749,101.01638$ & $4.2 \mathrm{~km}$ downstream of discharge point \\
D & $4.50777,101.01888$ & $4.7 \mathrm{~km}$ downstream of discharge point \\
E & $4.50111,101.04611$ & $11.4 \mathrm{~km}$ downstream of discharge point \\
\hline
\end{tabular}

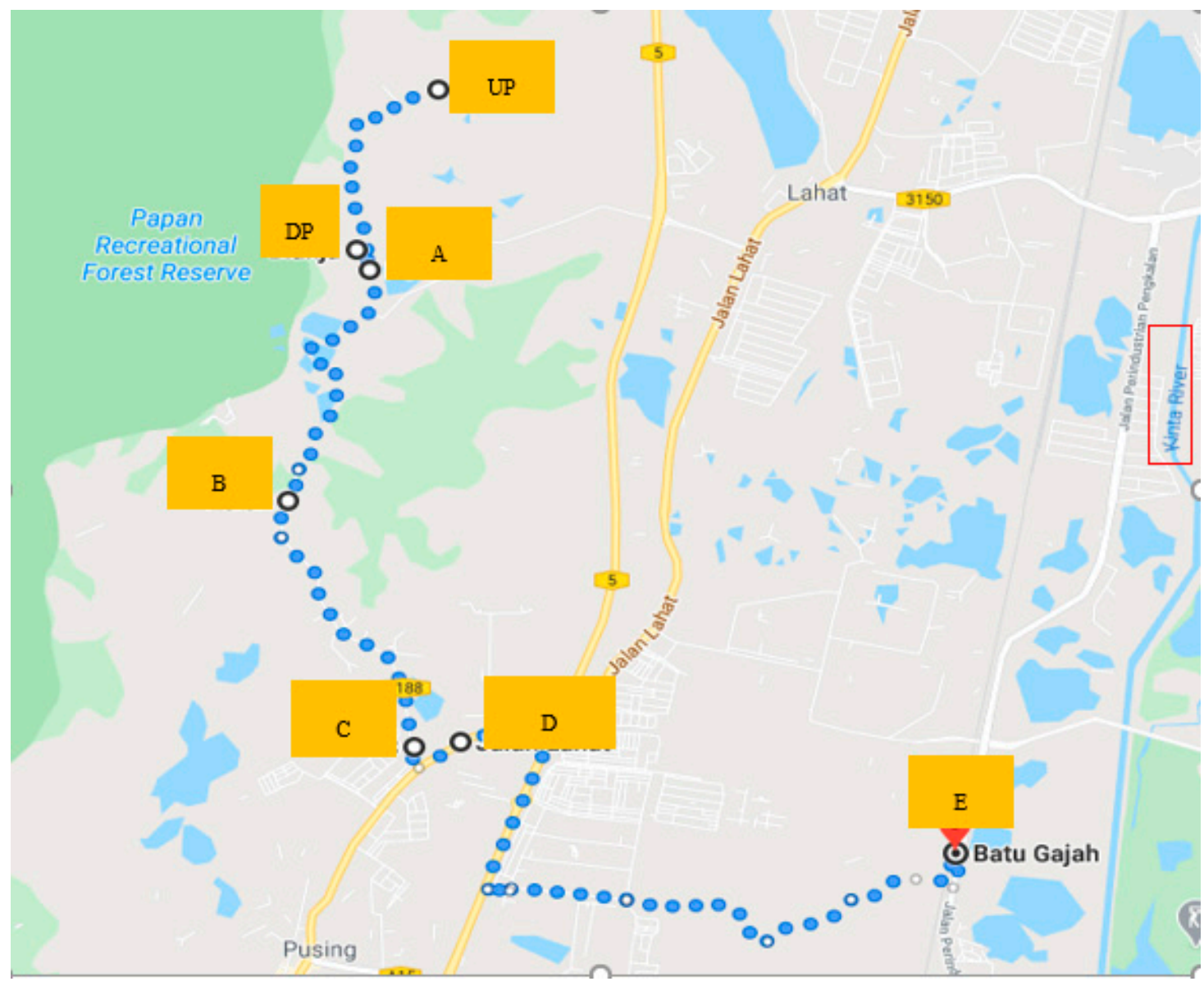

Figure 2. Sampling stations along Johan River.

\subsection{Materials and Methods}

Samples were analyzed following the standard methods for examination of water and wastewater [19]. The variables analyzed were $\mathrm{pH}$, dissolved oxygen, biological oxygen demand, chemical oxygen demand, total suspended solids, and ammoniacal nitrogen. Analyses were conducted in triplicate and results were expressed as averages.

\subsection{Water Quality Index (WQI)}

The status of a water body can be determined through its water quality index (WQI), which is an effective tool for assessing water quality by determining physico-chemical parameters. The Department of Environment (DOE), Malaysia stipulates calculation of WQI based on six parameters namely, 
dissolved oxygen (DO), biological oxygen demand (BOD), chemical oxygen demand (COD), ammoniacal nitrogen (AN), suspended solids (SS), and $\mathrm{pH}$. The range of the water quality index should be $0 \leq \mathrm{WQI} \leq 100$. The calculation and various sub-indices (SI) values are obtained based on Table 4 and WQI is then calculated using Equation (2). Table 5 shows the DOE water quality index classification.

$$
\mathrm{WQI}=0.22 \mathrm{SIDO}+0.19 \mathrm{SIBOD}+0.16 \mathrm{SICOD}+0.15 \mathrm{SIAN}+0.16 \mathrm{SISS}+0.12 \mathrm{SIpH}
$$

Table 4. Best fit equation for the estimation of various sub-indices values.

\begin{tabular}{|c|c|}
\hline \multicolumn{2}{|c|}{ Sub-Index for DO (in \% Saturation) (SIDO) } \\
\hline $\mathrm{SIDO}=0$ & for $x \leq 8$ \\
\hline $\mathrm{SIDO}=100$ & for $x \geq 92$ \\
\hline $\mathrm{SIDO}=-0.395+0.030 \mathrm{x}^{2}-0.00020 \mathrm{x}^{3}$ & for $8<x<92$ \\
\hline \multicolumn{2}{|c|}{ Sub-Index for BOD (SIBOD) } \\
\hline SIBOD $=100.4-4.23 x$ & for $x \leq 5$ \\
\hline SIBOD $=108 \times \exp (-0.055 x)-0.1 x$ & for $x>5$ \\
\hline \multicolumn{2}{|c|}{ Sub-Index for COD (SICOD) } \\
\hline SICOD $=-1.33 x+99.1$ & for $x \leq 20$ \\
\hline $\operatorname{SICOD}=103 \times \exp (-0.0157 x)-0.04 x$ & for $x>20$ \\
\hline \multicolumn{2}{|c|}{ Sub-Index for $\mathrm{NH}_{3}-\mathrm{N}$ (SIAN) } \\
\hline SIAN $=100.5-105 x$ & for $x \leq 0.3$ \\
\hline SIAN $=94 \times \exp (-0.573 x)-5 \times|x-2|$ & for $0.3<x<4$ \\
\hline $\mathrm{SIAN}=0$ & for $x \geq 4$ \\
\hline \multicolumn{2}{|c|}{ Sub-Index for SS (SISS) } \\
\hline SISS $=97.5 \times \exp (-0.00676 x)+0.05 x$ & for $x \leq 100$ \\
\hline SISS $=71 \times \exp (-0.0061 x)+0.015 x$ & for $100<x<1000$ \\
\hline SISS $=0$ & for $x \geq 1000$ \\
\hline \multicolumn{2}{|c|}{ Sub-Index for $\mathrm{pH}(\mathrm{SIpH})$} \\
\hline $\mathrm{SIpH}=17.02-17.2 x+5.02 x^{2}$ & for $x<5.5$ \\
\hline SIpH $=-242+95.5 x-6.67 x^{2}$ & for $5.5 \leq x<7$ \\
\hline SIpH $=-181+82.4 x-6.05 x^{2}$ & for $7 \leq x<8.75$ \\
\hline $\mathrm{SIpH}=536-77.0 x+2.76 x^{2}$ & for $x \geq 8.75$ \\
\hline
\end{tabular}

Table 5. DOE water quality index classification.

\begin{tabular}{ccccccc}
\hline \multirow{2}{*}{ Parameter } & Unit & \multicolumn{7}{c}{ Class } \\
\cline { 3 - 7 } & & I & II & III & IV & V \\
\hline Ammoniacal nitrogen & $\mathrm{mg} / \mathrm{L}$ & $<0.1$ & $0.1-0.3$ & $0.3-0.9$ & $0.9-2.7$ & $>2.7$ \\
Biological oxygen & $\mathrm{mg} / \mathrm{L}$ & $<1$ & $1-3$ & $3-6$ & $6-12$ & $>12$ \\
demand & $\mathrm{mg} / \mathrm{L}$ & $<10$ & $10-25$ & $25-50$ & $50-100$ & $>100$ \\
Chemical oxygen demand & $\mathrm{mg} / \mathrm{L}$ & $>7$ & $5-7$ & $3-5$ & $1-3$ & $<1$ \\
Dissolved oxygen & - & $>7$ & $6-7$ & $5-6$ & $<5$ & $>5$ \\
pH & $\mathrm{mg} / \mathrm{L}$ & $<25$ & $25-50$ & $50-150$ & $150-300$ & $>300$ \\
Total suspended solids & & & & & &
\end{tabular}

\subsection{PAH Analysis}

The 16 priority PAHs in the samples were identified and quantified using gas chromatography-mass spectrometry after liquid-liquid extraction [10,11]. In total, $100 \mathrm{~mL}$ water sample was measured and added into a $500 \mathrm{~mL}$ separating funnel equipped with a cap and a stand. Next, $25 \mathrm{~mL}$ dichloromethane (DCM) (Merck, CAS No: 75-09-2) was added into the separating funnel containing the water sample. The mixture was shaken vigorously and vapors were released slowly 
until no more vaporization arose from the mixture. The separating funnel was left to stand for a few minutes until two layers of liquid were observed. The lower layer was carefully withdrawn into a $125 \mathrm{~mL}$ conical flask. Then, $12.5 \mathrm{~mL}$ dichloromethane was used twice by repeating the above extraction procedure. The extracted sample was added with anhydrous sodium sulphate to absorb moisture until a clear solution was observed. The sample was filtered with filter paper (Whatman, CAT No: 1001 125) $125 \mathrm{~mm}$ pore size into a new $125 \mathrm{~mL}$ conical flask. The filtered sample was placed in a Buchi R-215 rotary evaporator equipped with a heating bath (Buchi B-491), vacuum pump (Buchi V-700), recirculating chiller (Buchi F-100), and vacuum controller (Buchi V-850) to evaporate until the volume reduced to $1.5 \mathrm{~mL}$. The solvent was transferred into an $8 \mathrm{~mm}$ gas chromatography-mass spectrometry (GCMS) vial containing $1 \mathrm{~mL}$ acetonitrile (Merck, CAS No: 75-05-8) prior to PAH detection. The GCMS used was Agilent, model G7035A combination of 7820A GC system with 5977E MSD. It employed a Shimadzu 221-75954-30 column. The column temperature setting was $60-200{ }^{\circ} \mathrm{C}$ at $200{ }^{\circ} \mathrm{C} / \mathrm{min}$, then increased at $70^{\circ} \mathrm{C} / \mathrm{min}$ to $300^{\circ} \mathrm{C}$. The injector and transfer line temperature were 300 and $280^{\circ} \mathrm{C}$. Selected ion monitoring (SIM) mode was used for data monitoring. Helium was used as carrier gas.

\subsection{ANN Data Processing and Model Development}

An artificial neural network (ANN) is a structure that functions like the human biological neural system that processes information through many interconnected units of neurons. These neurons are arranged in three layers, i.e., input, hidden, and output layers that are linked together in an orderly manner to optimize the final output. This system has an advantage of fixing problems that relate to huge data sets and complicated non-linear relations among the different inputs. Besides, ANN is also widely applied to determine complex patterns in data sets that could not be displayed by a numerical formula [20]. In recent years, ANN has become very popular in many areas of water science such as in the forecast of chemical oxygen demand [21], water quality index, and study related to hydrological modelling [22]. Feed-forward network is the most common type of neural network architecture that typically consists of input, hidden, and output layers. ANN model development and appropriate selection of respective parameters in this study is explained in the following sections.

\subsubsection{Selection of Input Data and Statistical Analyses}

Monthly data of water quality parameters were collected over a one-year period at different sampling locations. Input water quality parameters for WQI-ANN were biological oxygen demand (BOD), chemical oxygen demand (COD), total suspended solids (TSS), ammoniacal nitrogen (AN), dissolved oxygen (DO), and $\mathrm{pH}$. The data was randomly divided as 24 samples (70\%) for training set, 5 samples $(15 \%)$ for testing, and the rest (15\%) for validation in the wet and dry seasons. Moreover, 16 parameters were set as input for TEC-ANN, i.e., naphthalene, acenaphthylene, acenaphthene, fluorene, phenanthrene, anthracene, fluoranthene, pyrene, benzo(a)anthracene, chrysene, benzo(k)fluoranthene, benzo(b)fluoranthene, benzo(a)pyrene, dibenzo(a,h)anthraces, benzo(g,h,i)perylene, and indeno(1,2,3cd)pyrene. Data was randomly divided into $80 \%$ in training set, $10 \%$ in testing, and the rest for validation (10\%). Statistical parameters such as mean, maximum, minimum, and standard deviation (SD) were determined to examine the complexity and variability of the data. ANN model structure was created with the MATLAB ANN toolbox (R 2018 a).

\subsubsection{Selection of ANN Architecture}

The model structure used in this study consists of three layers (input, hidden, and output). Mustafa et al. [23] stated that the trial and error method can be a way to establish the optimal number of hidden neurons. It is obtained by determining the minimum number of neurons required to produce the least network error at testing, training, and validation phases. Thus, after performing trial and error, the optimum number of neurons in the hidden layer was set as 10. In WQI-ANN, the output of the model was fixed as 1, which is the water quality index (WQI). Therefore, the ANN architecture for this study was 6-10-1, as illustrated in Figure 3 (where 6, 10, and 1 represent the number of neurons 
in the input, hidden, and output layers, respectively). For TEC-ANN, the architecture adopted was 16-10-1 (Figure 4) (where 16, 10, and 1 are the number of neurons in the input, hidden, and output layers, respectively).

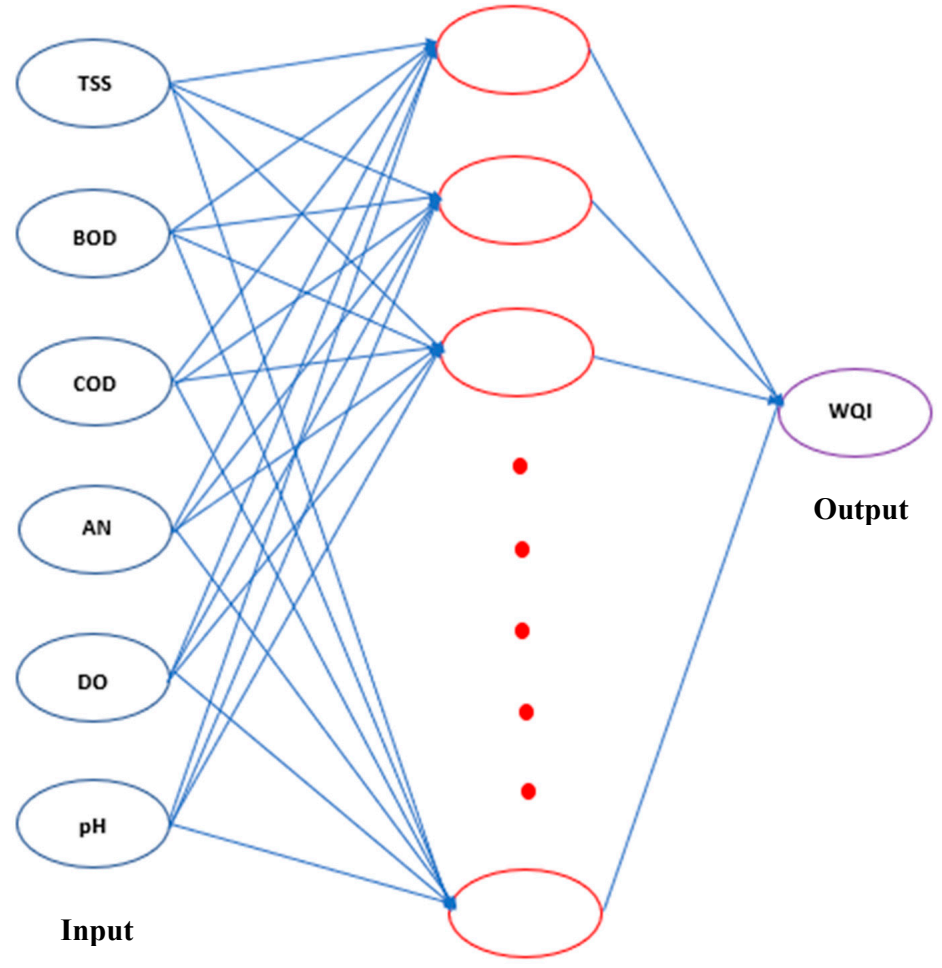

Figure 3. Architecture of WQI-ANN.

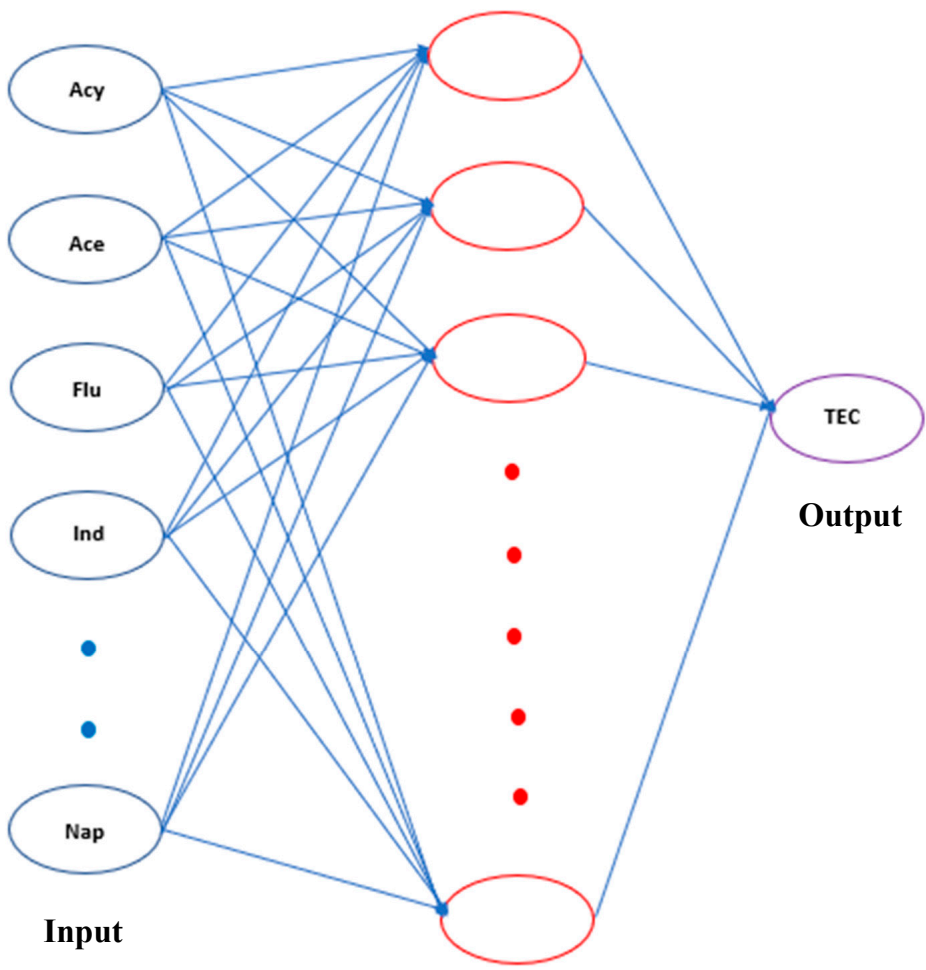

Figure 4. Architecture of TEC-ANN. 


\subsubsection{Selection of Training Algorithm}

The scaled conjugate gradient (SCG) method was chosen as the algorithm in the WQI-ANN study due to its highly optimized characteristics. This method employs a step size scaling mechanism that avoids time-consuming line searches per learning iteration [24]. This algorithm could also present super-linear convergence for most of the issues faced, which minimizes a multi-dimensional target function. Mustafa et al. [25] carried out a study focusing on suspended sediment discharged into a river and noted that regular back propagation algorithm is slower compared to SCG. It was reported that the SCG method based on the second order gradient supervised learning rule are 20 times quicker. Moreover, limited studies have attempted to use SCG technique for modelling of WQI data. The Levenberg-Marquardt (LM) training algorithm was adopt for TEC-ANN modelling in this study as prediction of micropollutants using LM algorithm was limited.

\subsubsection{Selection of Performance Evaluation Measures}

Assessment of trained model in a training set can be done by comparing its predicted value to a corresponding measured value in the overfitting test set. These values are determined and calibrated by adapting different model parameters systematically. Performance evaluation statistics used for ANN training in the present work are the mean square error (MSE), root mean square error (RMSE), and correlation coefficient (Rp). Rp was intended to measure the strength and direction of a linear relationship between two variables, whereas RMSE was applied to measure the difference between actual output parameter (i.e., WQI and TEC) values and the values obtained from prediction models. The desired value of RMSE is zero [23]. The equations used for calculating these parameters are as follows:

$$
\begin{gathered}
\text { MSE }=\frac{1}{R} \sum_{r=1}^{R}\left(z_{r}-y_{r}\right) \\
\operatorname{RMSE}=\left[\frac{1}{R} \sum_{r=1}^{R}\left(z_{r}-y_{r}\right)\right]^{1 / 2} \\
\operatorname{Rp}=\left[\frac{\sum_{r-1}^{R}\left[\left(z_{r}-\overline{z_{r}}\right)\left(y_{r}-\overline{y_{r}}\right)\right]}{\sum_{r-1}^{R}\left[\left(z_{r}-\overline{z_{r}}\right)^{2} \sum_{r-1}^{R}\left(y_{r}-\overline{y_{r}}\right)^{2}\right]}\right]
\end{gathered}
$$

where $z_{r}$ and $y_{r}$ are observed and predicted values, respectively; $\overline{z_{r}}$ and $\overline{y_{r}}$ are mean of observed and predicted values, respectively; and $\mathrm{R}$ is the total number of observations for which the error is computed.

\subsubsection{Selection of the Stopping Criteria}

The stopping criteria of training was predefined at a maximum of 100 epochs. Training was terminated when the maximum number of epochs was reached.

\section{Results and Discussion}

\subsection{Characteristics of Raw and Treated Leachate}

The composition of leachate generated is time and site specific and depends on the characteristics of deposited wastes. Raw leachate is the liquid found at the bottom of waste piles in a landfill. It is usually collected by a leachate pipe. Treated leachate refers to the effluent obtained after raw leachate has been treated prior to discharge in the environment (river). The variation in physico-chemical parameters for raw leachate (RL) and treated leachate (TL) from the Papan landfill are shown in Figure 5a-f; Table 6 presents their summary. The average values of BOD, COD, TSS, AN, DO, and pH for RL were $2292 \mathrm{mg} / \mathrm{L}, 11,339 \mathrm{mg} / \mathrm{L}, 27.3 \mathrm{mg} / \mathrm{L}, 1054 \mathrm{mg} / \mathrm{L}, 0.61 \mathrm{mg} / \mathrm{L}$, and 8.06, respectively. The corresponding values for TL were $2.3 \mathrm{mg} / \mathrm{L}, 29.9 \mathrm{mg} / \mathrm{L}, 11.3 \mathrm{mg} / \mathrm{L}, 0.18 \mathrm{mg} / \mathrm{L}, 7.44 \mathrm{mg} / \mathrm{L}$, and 7.55 (Table 6). COD values were found to be lower from studies conducted by Zazoulif et al. [26] and Yilmaz et al. [27], who reported 
average COD in RL to be $40,157 \mathrm{mg} / \mathrm{L}$ and $38,200 \mathrm{mg} / \mathrm{L}$, respectively. Another study reported by Jumaah et al. [28] found that the average BOD, COD, AN, pH, and TSS of leachate samples collected at the Jeram Sanitary Landfill were 14,790 mg/L, 49,000 mg/L, $3800 \mathrm{mg} / \mathrm{L}, 8.65$, and $5348 \mathrm{mg} / \mathrm{L}$, respectively. The concentrations detected in the above studies were relatively higher compared to this study. However, the difference in characteristics of leachate from different landfills were attributed to many factors and conditions including season and weather conditions, landfill waste composition, landfill age, and operation mode [29]. The studied landfill was in tropical weather, i.e., humid with average temperature of $20-30{ }^{\circ} \mathrm{C}$.
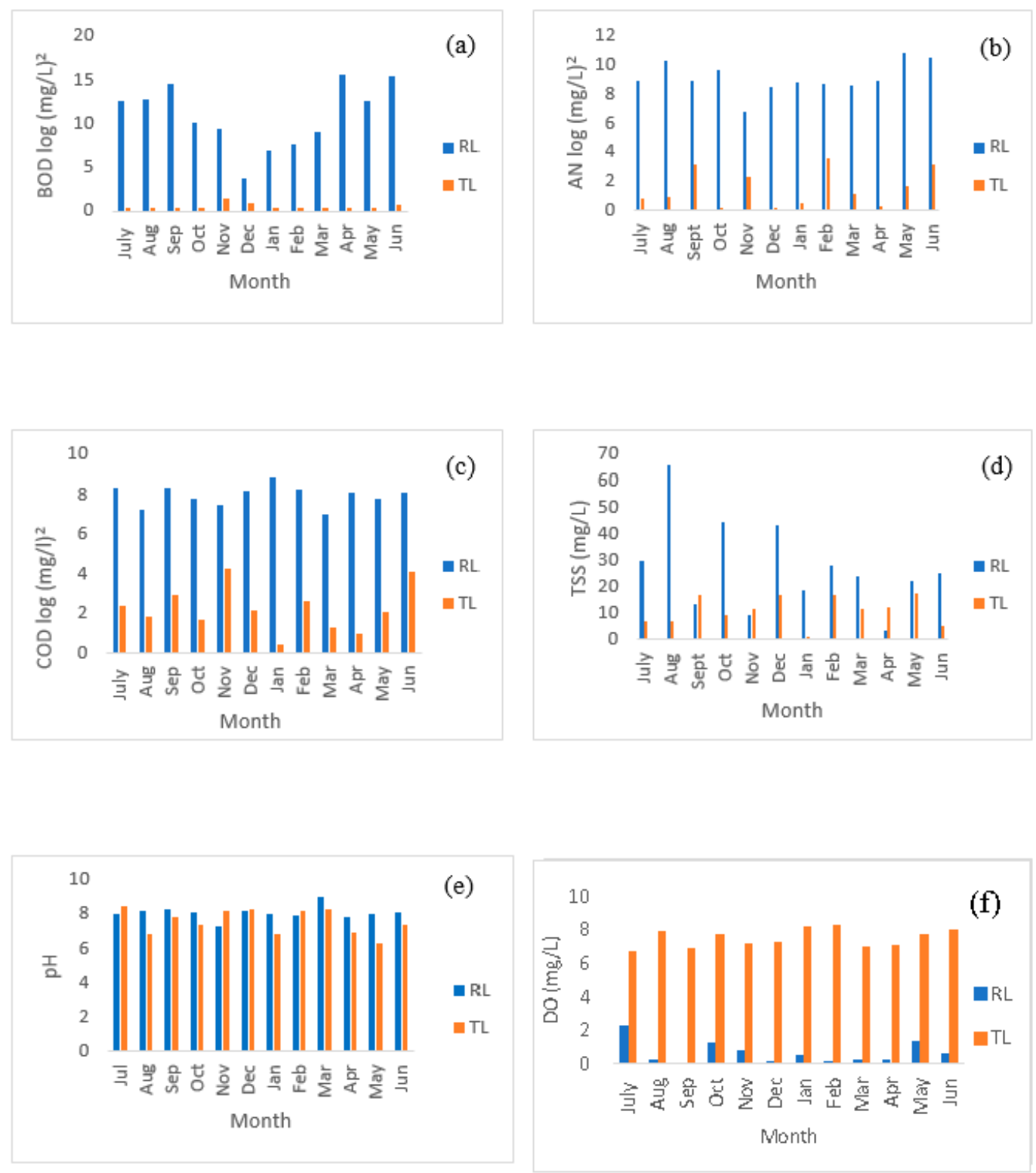

Figure 5. Variation in water quality parameters. (a): BOD, (b): AN (c): COD, (d): TSS, (e): pH, and (f): DO for raw and treated leachate.

Results show that TL had higher DO, much lower BOD, COD, AN, and TSS, and slightly lower pH compared to RL. This indicates that the landfill has an effective and efficient treatment system for RL. Raw leachate was stored in two storage ponds before being sent to a flocculator to produce sludge. Then, the sludge and water were separated by dissolved air floatation. $\mathrm{pH}$ was adjusted before passing the leachate to a sequencing batch reactor (SBR) for biological treatment. Traditionally, biological treatment 
is often chosen for treatment because it is reliable, easy to run, and highly cost-effective in organic compound removal. Pollutants are destroyed and transformed into non-hazardous and simple products after treatment. Thereafter, the wastewater is pumped to a buffer tank, sand filter, carbon filter, and ozone tank before being finally discharged to the receiving Johan River. The physicochemical parameters of TL were found to meet the standard limits set by the Environmental Quality (Control of Pollution from Solid Waste Transfer Station and landfill) Regulation 2009. Thus, the treatment plant in the Papan landfill was shown to treat the leachate adequately.

Table 6. Summary of physico-chemical parameters for raw and treated leachate.

\begin{tabular}{ccccccccc}
\hline \multirow{2}{*}{ Parameters } & \multicolumn{3}{c}{ Raw Leachate (RL) } & \multicolumn{3}{c}{ Treated Leachate (TL) } \\
\cline { 2 - 9 } & $\begin{array}{c}\text { Min } \\
(\mathbf{m g} / \mathrm{L})\end{array}$ & $\begin{array}{c}\text { Max } \\
(\mathbf{m g} / \mathrm{L})\end{array}$ & $\begin{array}{l}\text { Average } \\
(\mathbf{m g} / \mathrm{L})\end{array}$ & SD & $\begin{array}{c}\text { Min } \\
(\mathbf{m g} / \mathrm{L})\end{array}$ & $\begin{array}{c}\text { Max } \\
(\mathbf{m g} / \mathbf{L})\end{array}$ & $\begin{array}{l}\text { Average } \\
(\mathbf{m g} / \mathrm{L})\end{array}$ & SD \\
\hline BOD & 280 & 5160 & 2292 & 1406 & 0.11 & 15.7 & 2.3 & 4.31 \\
COD & 3344 & 29,107 & 11,339 & 6879 & 1.7 & 135.7 & 29.9 & 45 \\
TSS & 3.3 & 65.7 & 27.3 & 17.2 & 1.2 & 17.7 & 11.3 & 5.4 \\
AN & 395 & 1930 & 1054 & 418.7 & 0.013 & 0.79 & 0.18 & 0.23 \\
DO & 0.06 & 2.2 & 0.61 & 0.66 & 6.7 & 8.21 & 7.44 & 0.54 \\
pH & 7.28 & 9.03 & 8.06 & 0.39 & 6.33 & 8.4 & 7.55 & 0.72 \\
\hline
\end{tabular}

\subsection{Water Quality of the Johan River at Sampling Stations}

In this study, water samples were collected at seven sampling stations and analyzed for water quality parameters for a one-year duration. The results are displayed in Figure 6a-f. In general, BOD and COD ranged from 0.28 to $13 \mathrm{mg} / \mathrm{L}$ and 2.66 to $137 \mathrm{mg} / \mathrm{L}$, respectively. The lowest BOD value recorded was at a discharge point. The lowest $C O D$ recorded was at station $C$. The highest BOD recorded was at station $C$ and the highest COD was recorded at station D. It is seen that there were significant differences among sampling stations for both BOD and COD parameters. Along the river from upstream to downstream, concentrations of $\mathrm{BOD}$ and $\mathrm{COD}$ are generally found to have increased. This could be due to anthropogenic activities or industrial effluents released into the river. The water quality falls under Class III based on DOE classification. In order words, intensive treatment is required to make it suitable for drinking purposes.

Ammoniacal nitrogen at the sampling stations ranged from $0.69 \mathrm{mg} / \mathrm{L}$ to $5.36 \mathrm{mg} / \mathrm{L}$ and fell into Classes IV and V. Water with an AN value between 0.9 and $2.7 \mathrm{mg} / \mathrm{L}$ was only suitable for plant and domestic animal uses, whereas AN values greater than $2.7 \mathrm{mg} / \mathrm{L}$ indicated that water could be used for purposes listed in Classes I-IV (Table 5). Total suspended solids were generally below $150 \mathrm{mg} / \mathrm{L}$, which indicated that the river was in Class III and thus not suitable for drinking without intensive treatment. The exceptionally high TSS values in October were attributed to influx of sediments due to heavy rain. Strong stream currents resulting from precipitation eroded soil and sand around the river. The $\mathrm{pH}$ of the water samples varied between 5.75 to 9.03 and fell into Class I, i.e., the water was safe for consumption.

There was a general trend of deteriorating water quality going from upstream to downstream particularly at stations C, D, and E. This was because these points were located near municipal, agricultural, and industrial areas where wastewater discharge and surface runoff could enter the river system and affect its status. Anthropogenic activities were reported as reasons that contributed to low water quality status $[30,31]$. This was because discharged wastes often contain amounts high organic compounds and chemicals persistent in nature. Dissolved oxygen showed a generally decreasing trend from upstream to downstream sampling stations. This corroborates well with the increase in organic pollution shown by the BOD and COD trends. DO values varied between $2.57 \mathrm{mg} / \mathrm{L}$ and $8.62 \mathrm{mg} / \mathrm{L}$. Most of the values were within 5 to $7 \mathrm{mg} / \mathrm{L}$, which indicated that DO fell into Class II. 

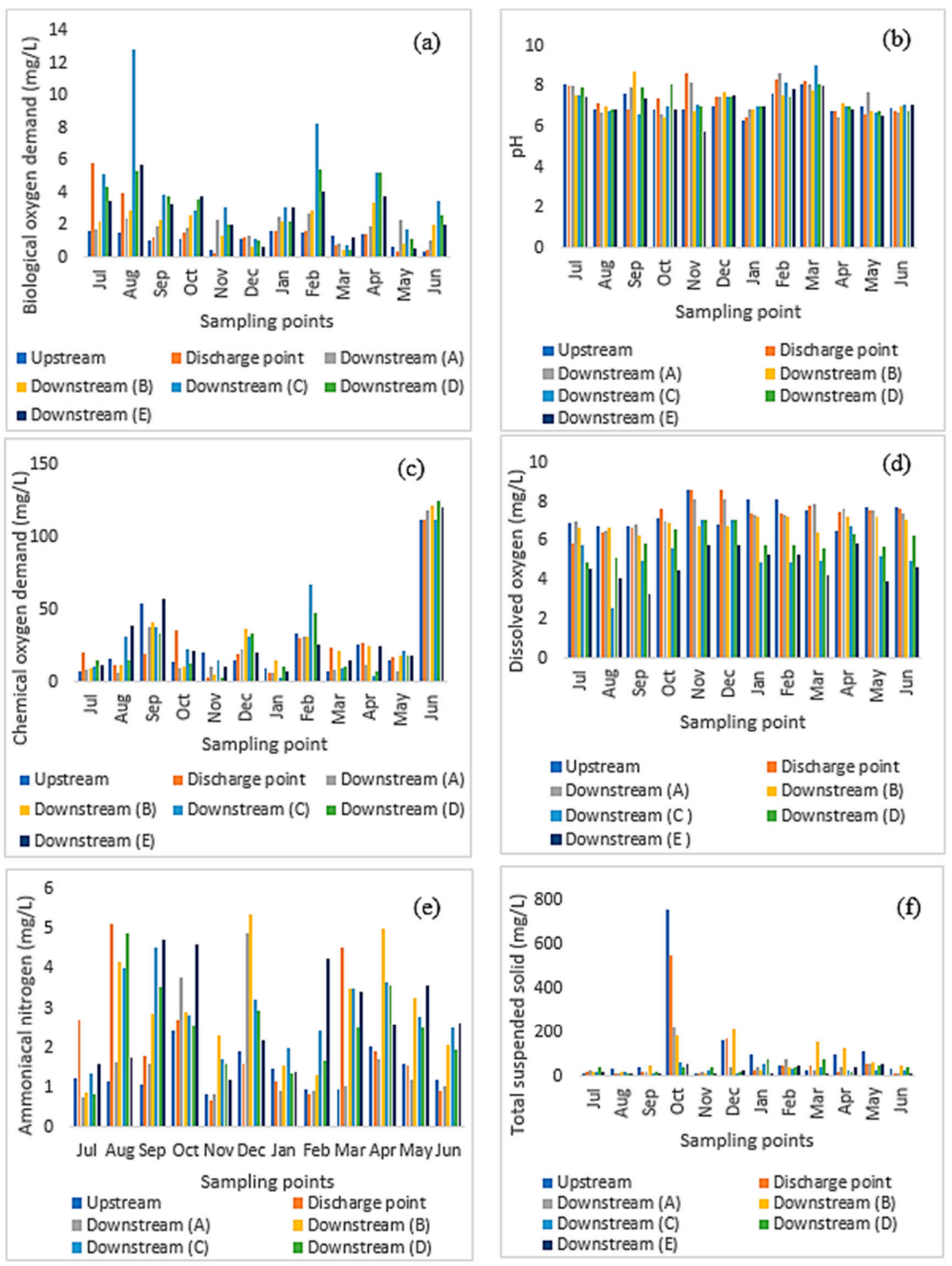

Figure 6. Water quality parameters. (a): $\mathrm{BOD},(\mathbf{b}): \mathrm{pH},(\mathbf{c})$ : $\mathrm{COD},(\mathbf{d}): \mathrm{DO}(\mathbf{e}): \mathrm{AN}$, and (f): TSS at each point along the Johan River.

In comparison, Hassan et al. [32] conducted a study on WQI in Pelus River, Perak. The results revealed that WQI of all stations were Class III during both the dry and wet seasons. WQI in the dry season was in the range of 71.9-74.58 and in the wet season was in the range of 54.06-88.6. Water quality of Pelus River was affected by land use activities such as clearing of land, forest burning, and soil erosion. In addition, Mohd at al. [30] reported that WQI of Segamat River was mostly classified in Class III in the wet and dry seasons. Deterioration of water quality of the river was caused by urban activities such as waste discharged at the Segamat town area. Surface runoff from agricultural land was high in TSS and BOD values, as it brought along debris such as soil, rotting trees, fertilizers, pesticides, and rotten palm oil fruits into the river. Alssgeer et al. [31] revealed that the Nerus River, Terengganu fell into Class III. Water quality worsened in the Nerus River were anthropogenic pollution sources due 
to high urbanization and agricultural activities. These as well as the current study showed that WQI of the rivers was in Class III (Tables 6 and 7). This indicated that water quality should be monitored and the water should be treated before drinking and consumption by human beings. Water pollution is closely related to waterborne diseases caused by fecal bacteria. Chemical wastes from industrial areas is another factor that contributes to contaminated water supply. Thus, regular monitoring and assessment of river water should be conducted for better water resource management and safeguard of environmental health.

Table 7. Average of 16 PAHs concentration in the wet and dry season.

\begin{tabular}{ccccccc}
\hline \multirow{2}{*}{ Station } & \multicolumn{6}{c}{ Concentration (ppb) } \\
\cline { 2 - 7 } & \multicolumn{7}{c}{ Dry Season } & \multicolumn{3}{c}{ Wet Season } \\
\cline { 2 - 7 } & Min & Max & Mean & Min & Max & Mean \\
\hline Upstream & 1.4 & 77.0 & 29.2 & 0 & 9.6 & 1.8 \\
Discharge point & 0.4 & 20.8 & 7.5 & 0.008 & 7.99 & 2.0 \\
A & 0.4 & 23.0 & 6.2 & 0 & 5.5 & 1.6 \\
B1 & 0.7 & 31.0 & 10.8 & 0 & 8.3 & 1.6 \\
C1 & 2.4 & 67.9 & 19.4 & 0.7 & 8.5 & 3.3 \\
D1 & 0 & 54.3 & 13.9 & 0 & 6.9 & 1.9 \\
E1 & 0.2 & 84.1 & 14.8 & 0 & 6.3 & 1.5 \\
B2 & 1.6 & 83.2 & 24.2 & 1.1 & 21.1 & 8.8 \\
C2 & 0 & 7.2 & 2.4 & 0 & 5.6 & 2.1 \\
D2 & 0 & 11.0 & 4.0 & 0.4 & 12.1 & 3.6 \\
E2 & 0 & 4.3 & 1.1 & 0 & 8.8 & 1.7
\end{tabular}

Note that B1, C1, D1, E1 and B2, C2, D2, E2 are reading numbers. For example: B2 is the second reading of point B1.

\subsection{Average PAHs in Raw and Treated Leachate}

The results shown in Figures 7 and 8 pertain to the 16 priority PAHs investigated in this study. The mean concentration of PAHs in raw and treated leachate in the dry season was $85.4 \mathrm{ppb}$ and $141.3 \mathrm{ppb}$, respectively (Figure 7). In the wet season, the mean concentration of PAHs in raw and treated leachate was $46.8 \mathrm{ppb}$ and $405.3 \mathrm{ppb}$, respectively. Basically, concentration of PAHs in TL was higher than that in RL in both the wet and dry seasons. Among all the PAHs, naphthalene was found to be dominant in raw leachate in both the wet and dry seasons (Figure 8). However, treated leachate had naphthalene dominance in the wet season but pyrene and fluoranthene in the dry season (Figure 8).

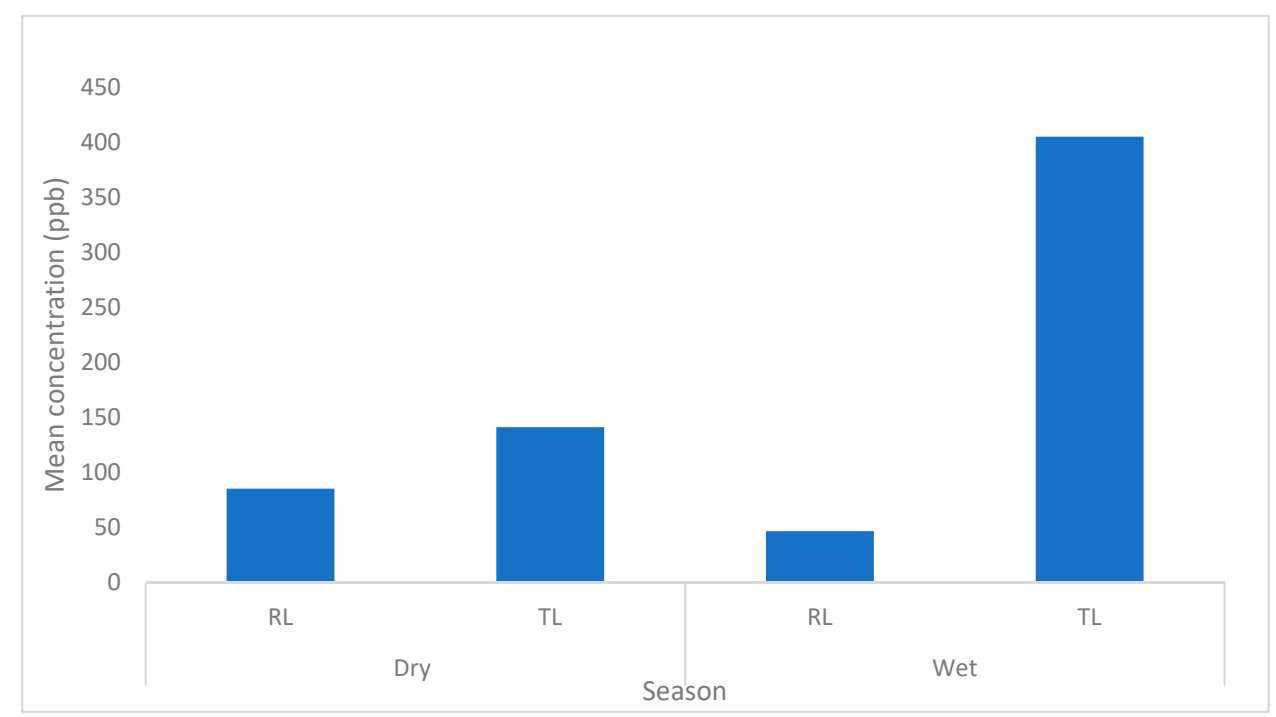

Figure 7. Mean concentration of PAHs in raw and treated leachate. 

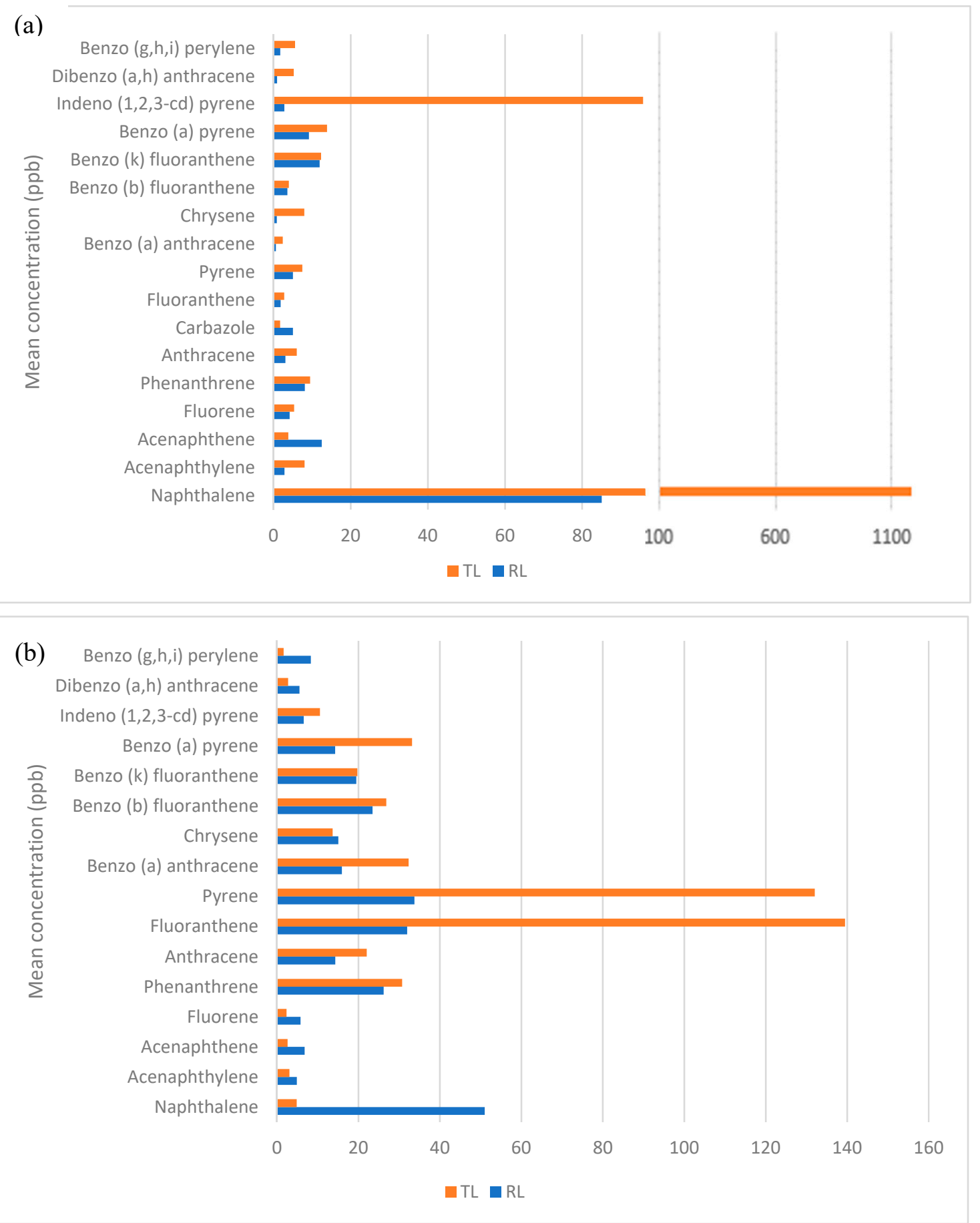

Figure 8. $(\mathbf{a}, \mathbf{b})$ : PAH in raw and treated leachate in the wet and dry seasons, respectively.

Naphthalene containing compounds disposed in landfills can originate from various sources. According to the Cancer Association of South Africa (CANSA) (2019), naphthalene (also known as tar camphor), white tar, or moth flakes are often used as chemical intermediates in the production of phthalic anhydride, naphthol, and chlorinated naphthalene. Naphthalene was found in surface water through naphthalene-containing organic chemicals used in industry plants, oil spills, and publicly operated treatment works (POTWs) sludge disposal (EPA, 2003). Fluoranthene is likely to occur through plant biosynthesis and pyrolytic processing of organic raw materials, such as coal and petroleum.

Jiries et al. [33] reported that the average PAHs concentration in leachate detected at Jordan landfill was $0.91 \mathrm{ppm}(910 \mathrm{ppb})$. Naphthalene and phenanthrene were the most abundant PAH in the leachate 
samples. The average PAHs concentration was higher than the results reported in the present study. Zdanevitch et al. [34] also noted that the concentration of naphthalene detected in landfill leachate was highest reaching at $1986 \mathrm{ng} / \mathrm{L}(1.986 \mathrm{ppb})$ compared to rest of the PAHs. In addition, Edokpayi et al. [35] reported PAH concentration in the range of $126-7510 \mu \mathrm{g} / \mathrm{L}(0.126-7.51 \mathrm{ppb})$ for Mvudi River and up to $7805 \mu \mathrm{g} / \mathrm{L}$ (7.805 ppb) for Nzhelele River, both in South Africa.

The overall mean concentration of PAHs detected in the wet season was higher compared to the dry season. Talalaj et al. [36] made a similar observation attributing it to intensive infiltration and pollutants leaching from wastes at times of high rainfall, as well as from washing out from road pavement contaminants coming from car exhausts, wearing off car tires, and from asphalt rich in hydrocarbon fractions, all of which could flow along with surface run-offs into the leachate reservoir. Chen et al. [37] reported that the PAHs found in surface water were originated from farmland that surrounded the sampling site and closely related to road dust and vehicle emissions. Kim and Young [38] detected extraordinarily high concentrations of PAHs in surface water, suggesting that surface runoff is a dominant contributor. It was presumed that PAHs accumulated during the long dry period were carried out by stormwater runoff into surface water.

The EU Directive 98/83/EC set a permissible level of $0.1 \mu \mathrm{g} / \mathrm{L}$ for PAHs in water intended for consumption by humans. The standard limit set by WHO was $50 \mathrm{ng} / \mathrm{L}$ and US EPA was $0.2 \mathrm{ppb}$ for benzo(a)pyrene. PAHs concentration reported in this study was above the standard limit and posed harm to human health and ecosystem. Thus, river quality should be controlled and the water treated adequately for PAHs contaminants.

\subsection{Distribution of PAHs in the Wet and Dry Seasons along Johan River}

PAHs results are tabulated in Table 7 and illustrated in Figure 9. The mean concentration of PAHs detected in the dry season were in the order of fluoranthene $>$ pyrene $>$ benzo [b] fluoranthene $>$ benzo [a] pyrene $>$ benzo [a] anthracene $>$ benzo [k] fluoranthene $>$ chrysene, and benzo [g,h,i] perylene $>$ phenanthrene $>$ anthracene $>$ indeno $[1,2,3-c d]$ pyrene $>$ dibenzo $[a, h]$ anthracene $>$ naphthalene $>$ acenaphthene $>$ acenaphthylene $>$ fluorene. Meanwhile, in the wet season, the mean concentration of PAHs in the sites were in the order of benzo [a] pyrene $>$ benzo [k] fluoranthene, and benzo [b] fluoranthene $<$ fluoranthene and pyrene $>$ phenanthrene $>$ acenaphthene $>$ naphthalene $>$ anthracene $>$ benzo [a] anthracene $>$ chrysene and fluorene $>$ acenaphthylene $>$ dibenzo [a,h] anthracene $>$ indeno $[1,2,3-c d]$ pyrene, and benzo $[\mathrm{g}, \mathrm{h}, \mathrm{i}]$ perylene.

In the dry season, mean concentration of most PAHs in station upstream, discharge point, A, B1, C1, D1, E1, B2, C2, D2, and E2 was 29.2 ppb, 7.5 ppb, 6.2 ppb, 10.8 ppb, 19.4 ppb, 13.9 ppb, 14.8 ppb, $24.2 \mathrm{ppb}, 2.4 \mathrm{ppb}, 4 \mathrm{ppb}$, and $1.1 \mathrm{ppb}$, respectively, and for the wet season were $1.8 \mathrm{ppb}, 2 \mathrm{ppb}, 1.6 \mathrm{ppb}$, 1.6 ppb, 3.3 ppb, 1.9 ppb, $1.5 \mathrm{ppb}, 8.8 \mathrm{ppb}, 2.1 \mathrm{ppb}, 3.6 \mathrm{ppb}$, and $1.7 \mathrm{ppb}$. The concentration of PAHs gradually decreased from upstream to downstream. Mean concentration of PAHs in the dry season was higher compared to the wet season (Figure 9). High molecular weight (HMW) PAHs were found to contribute more towards total PAHs compared to low molecular weight (LMW) PAHs. The dominance of HMW PAHs ( $\geq 4$ rings) in both seasons was due to the increased resistance to oxidation, reduction, and vaporization as molecular weight increased [36], thus making them persistent in the environment especially in surface water. Fluoranthene (333.4 ppb) was found dominant in the dry season while benzo [a] pyrene (93.5 ppb) was found dominant in the wet season.

Li et al. [39] reported that concentrations of $\sum$ PAHs in water samples from the Aojiang River varied from a minimum of $909.9 \mathrm{ng} / \mathrm{L}(0.9 \mathrm{ppb})$ to a maximum of $1519.8 \mathrm{ng} / \mathrm{L}$ (1.5 ppb), 21.7-138 ng/L (0.02-0.138 ppb) in the Xijiang River and 12-130 ng/L (0.012-0.13 ppb) in the Susquehanna River. The main source of PAHs contamination in the Aojiang River was leather industry. Unregulated waste discharge from individual leather processing plants released wastewater directly into the Aojiang River without passing through the wastewater treatment plant was one of the factors that increased the PAHs concentration in the river. Adenji et al. [40] noted that individual levels of PAHs in the Buffalo River ranged from non-detected (ND) to $24.91 \mu \mathrm{g} / \mathrm{L}(24.91 \mathrm{ppb})$; mean value of the 16 PAHs 
was $76.06 \pm 11.01 \mu \mathrm{g} / \mathrm{L}$ and the most frequently detected PAH was benzo [a] anthracene. Discharge of industrial wastewater and accumulation of leachate at the creek possibly from an old solid waste landfill site, wastewater treatment facilities, and Wilsonia industrial and residential areas were factors that contributed to the high PAHs levels detected.

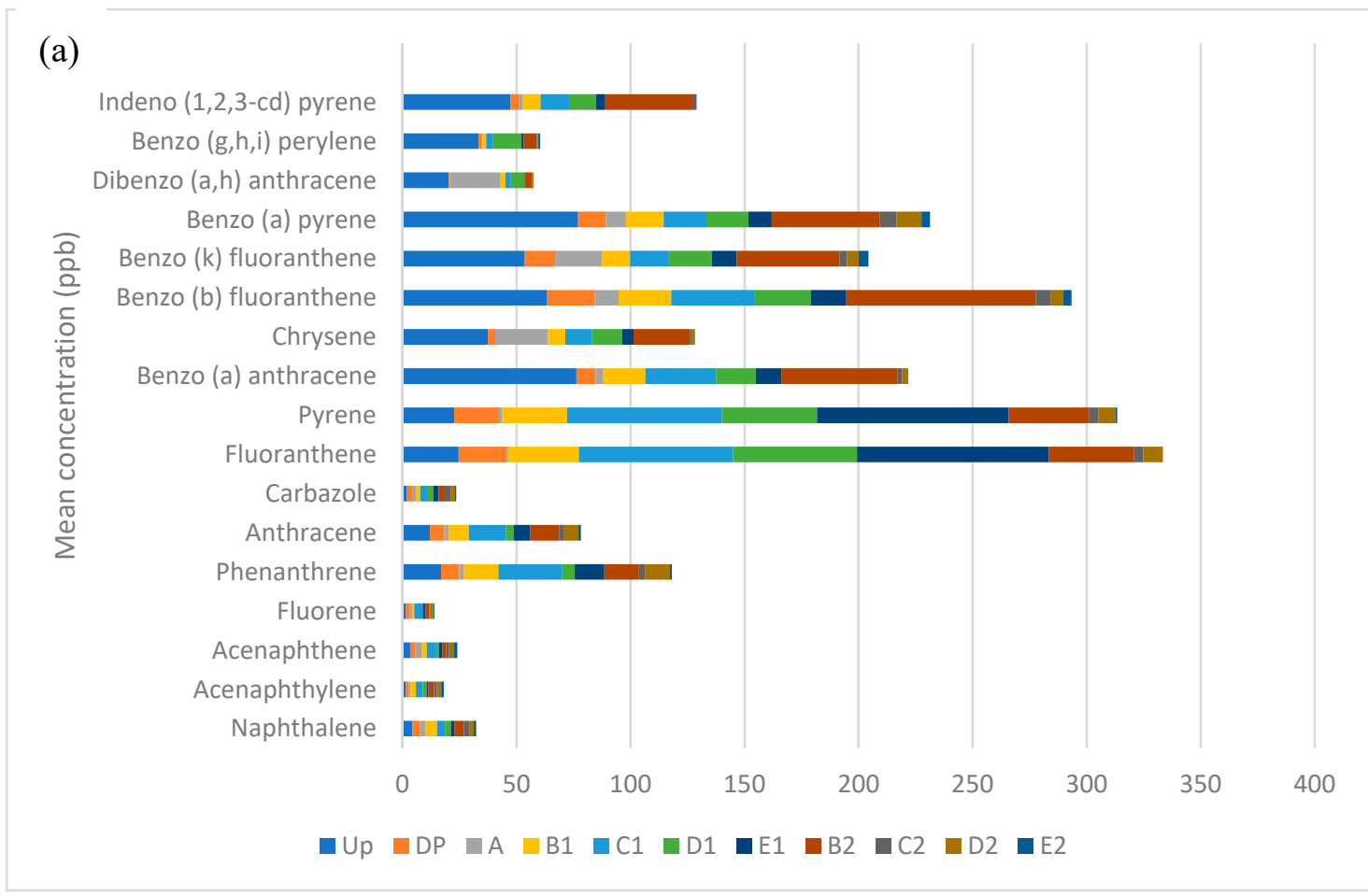

(b)

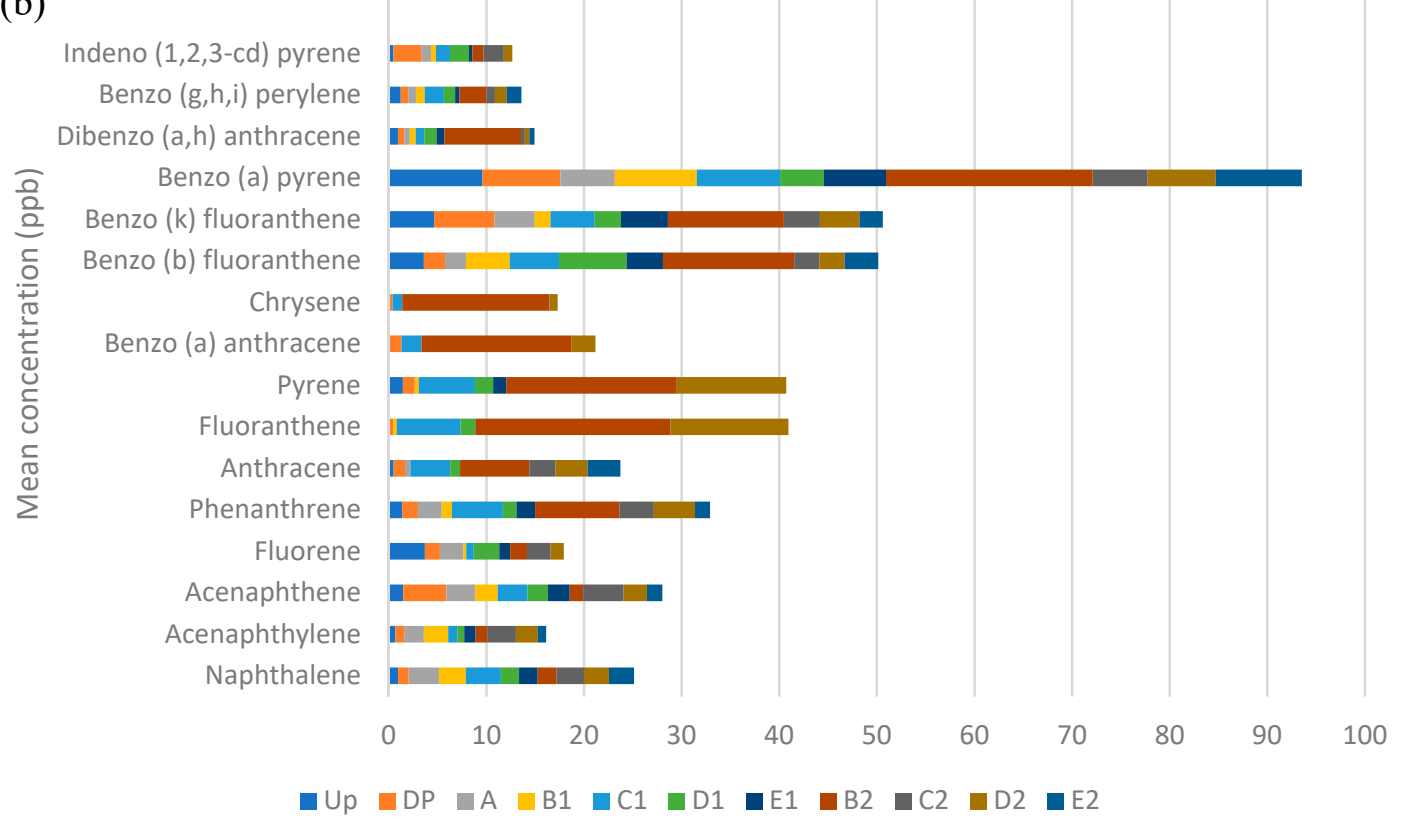

Figure 9. $(\mathbf{a}, \mathbf{b})$ : PAH detected in the dry and wet season respectively along the Johan River.

Generally, the concentration of PAHs detected in this study were above the permissible limit for drinking water which is $0.005 \mu \mathrm{g} / \mathrm{L}(0.005 \mathrm{ppb})(\mathrm{WHO}, 2006)$ and $0.2 \mathrm{ppb}$ for benzo(a)pyrene according to US EPA. According to Adeniji et al. [40], there are other possible sources of high PAHs in the 
water phase of aquatic systems, which include exhaust emission from transportation, intense shipping activities, and run-off from petroleum filling stations.

The accumulative effect of PAHs over time can be a threat to human life. According to Igwe and Ukaogo [41], exposure to PAHs can decrease immune function and cause cataract, kidney/liver damage, breathing problems, asthma like symptoms, and lung function abnormalities. Further, repeated contact with skin may induce redness and skin inflammation. Pashin and Bakhitova [42] stated that PAHs have carcinogenic properties from reactive metabolites, namely epoxides and dihydrodiols, that tend to bind with human body cellular protein and DNA resulting in mutations, developmental malformation, tumors, and cancer. It has been shown that approximately $90 \%$ of cancer occurring in humans were of chemical origin that resulted from the environment. It is probable that polycyclic aromatic hydrocarbons make their contributions in this respect. Thus, river water should be treated adequately before drinking and consumption.

\subsection{WQI-ANN Modelling}

WQI for a year period starting from July 2018 was calculated according to Section 2.4. The data was categorized into the wet (November-March) and dry (May-September) seasons. April and October were not included as they were transition months between the wet and dry seasons. Statistical parameters for the input and output data are shown in Tables 8 and 9. The data was randomly divided into 24 samples (70\%) in training set, 5 samples (15\%) in testing, and the rest was used for validation (15\%). Basically, the validation set was used to determine the correct time to stop training in order to avoid over-fitting, whereas the test set was used to assess the induction ability of the trained model and evaluate the predictability of the network [16].

Table 8. Summary of the input and output parameters for the wet season.

\begin{tabular}{cccccccc}
\hline Parameter & DO (mg/L) & BOD $(\mathbf{m g} / \mathbf{L})$ & COD $(\mathbf{m g} / \mathbf{L})$ & AN $(\mathbf{m g} / \mathbf{L})$ & TSS $(\mathbf{m g} / \mathrm{L})$ & pH & WQI \\
\hline Mean & 6.82 & 1.93 & 19.22 & 2.08 & 51 & 7.5 & 76.17 \\
Max & 8.62 & 8.21 & 67.67 & 5.36 & 209 & 9.0 & 91.14 \\
Min & 4.24 & 0.28 & 2.67 & 0.69 & 1.8 & 5.8 & 58.73 \\
SD & 1.20 & 1.59 & 14.14 & 1.27 & 50.7 & 0.7 & 8.52 \\
Class & II & II & II & IV & III & I & III \\
\hline
\end{tabular}

Table 9. Summary of the input and output parameters for the dry season.

\begin{tabular}{cccccccc}
\hline Parameter & DO (mg/L) & BOD $(\mathbf{m g} / \mathbf{L})$ & COD $(\mathbf{m g} / \mathbf{L})$ & AN $(\mathbf{m g} / \mathrm{L})$ & TSS $(\mathbf{m g} / \mathbf{L})$ & pH & WQI \\
\hline Mean & 6.02 & 2.76 & 41.47 & 2.31 & 27.9 & 7.2 & 73.27 \\
Max & 7.74 & 12.87 & 136.67 & 5.12 & 112 & 8.7 & 86.13 \\
Min & 2.57 & 0.41 & 6.33 & 0.77 & 2.5 & 6.6 & 46.32 \\
SD & 1.32 & 2.35 & 41.51 & 1.3 & 21.8 & 0.55 & 9.23 \\
Class & II & II & III & IV & II & I & III \\
\hline
\end{tabular}

The mean WQI values in the wet and dry seasons were 76.17 and 73.27, respectively. Both values fall in Class III (Table 1). The predicted outputs simulated by ANN were obtained and correlations were determined between the actual WQI and the predicted WQI by ANN. The results are shown in Figures 10-13. The results displayed clearly that the observed WQI values matched well with the predicted value of WQI in training phase in the wet and dry seasons (Figures 10 and 13). Rp values for actual and predicted WQI for the wet and dry seasons were 0.9915 and 0.9431 , respectively. In this study, the wet and dry seasons had Rp values close to 1 (Tables 10 and 11), which represented a strong relationship between the variables. Meanwhile, the performance of ANN in the wet season showed MSE of $0.491,4.726$, and 1.407 in the training, validation, and testing phases, as compared to MSE values of 3.430, 23.780, and 26.481 in the training, validation, and testing during the dry season. RMSE for the wet season were 0.7001 in training, 2.714 in validation, and 1.186 in testing, whereas, for the dry season, 
it was 1.852, 4.876, and 5.146 in the training, validation, and testing phases, respectively. MSE and RMSE were higher in the dry season compared to the wet season. Thus, the wet season indicated a better fit and higher accuracy in prediction.

Table 10. Performance of the ANN model for the wet season.

\begin{tabular}{cccc}
\hline Performance & MSE & RMSE & Rp \\
\hline Training & 0.491 & 0.7001 & 0.9964 \\
Validation & 4.726 & 2.174 & 0.9829 \\
Testing & 1.407 & 1.186 & 0.9948 \\
\hline
\end{tabular}

Table 11. Performance of the ANN model for the dry season.

\begin{tabular}{cccc}
\hline Performance & MSE & RMSE & Rp \\
\hline Training & 3.430 & 1.852 & 0.9790 \\
Validation & 23.780 & 4.876 & 0.8923 \\
Testing & 26.481 & 5.146 & 0.9429 \\
\hline
\end{tabular}

(a)

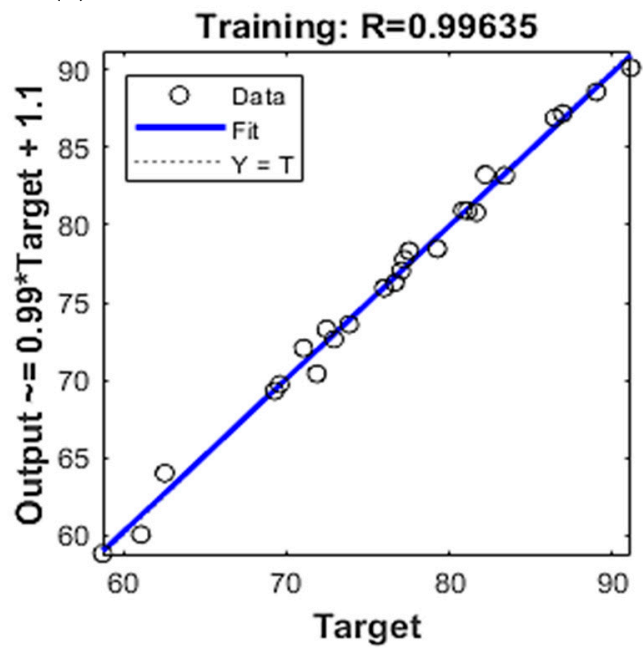

(c)

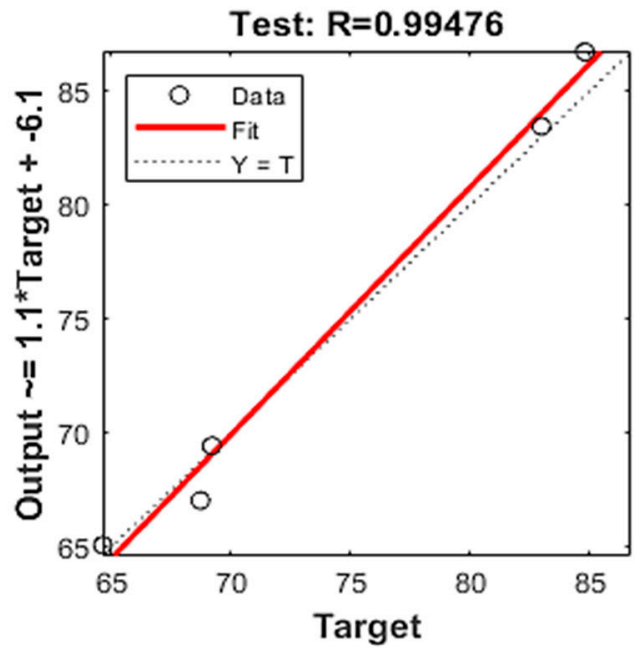

(b)

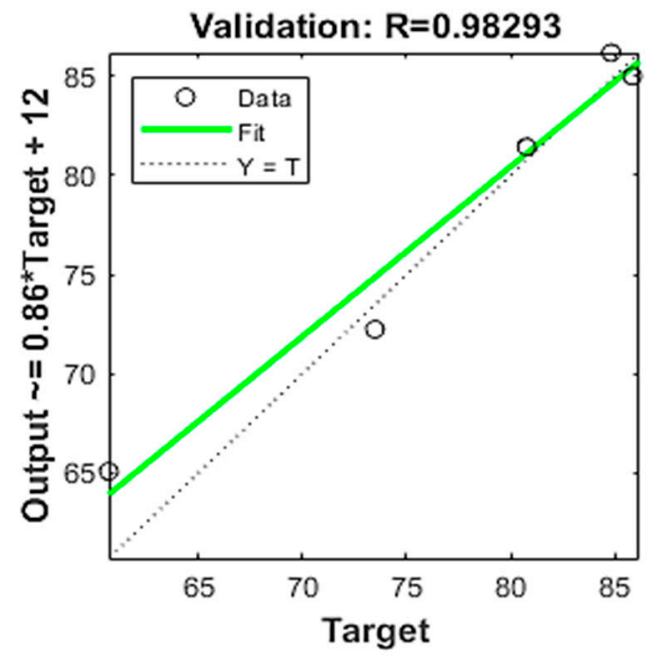

(d)

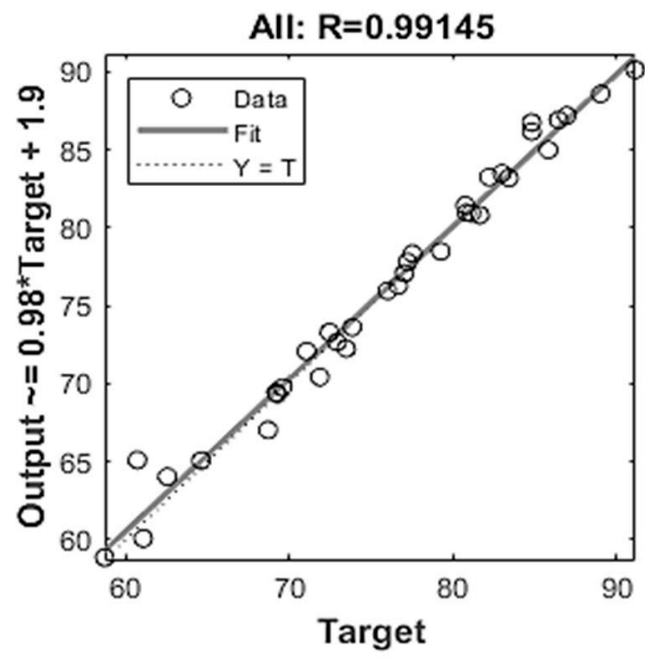

Figure 10. Comparison of predicted and observed WQI values during (a) training, (b) validation, and (c) testing phases (d) all during the wet season. 

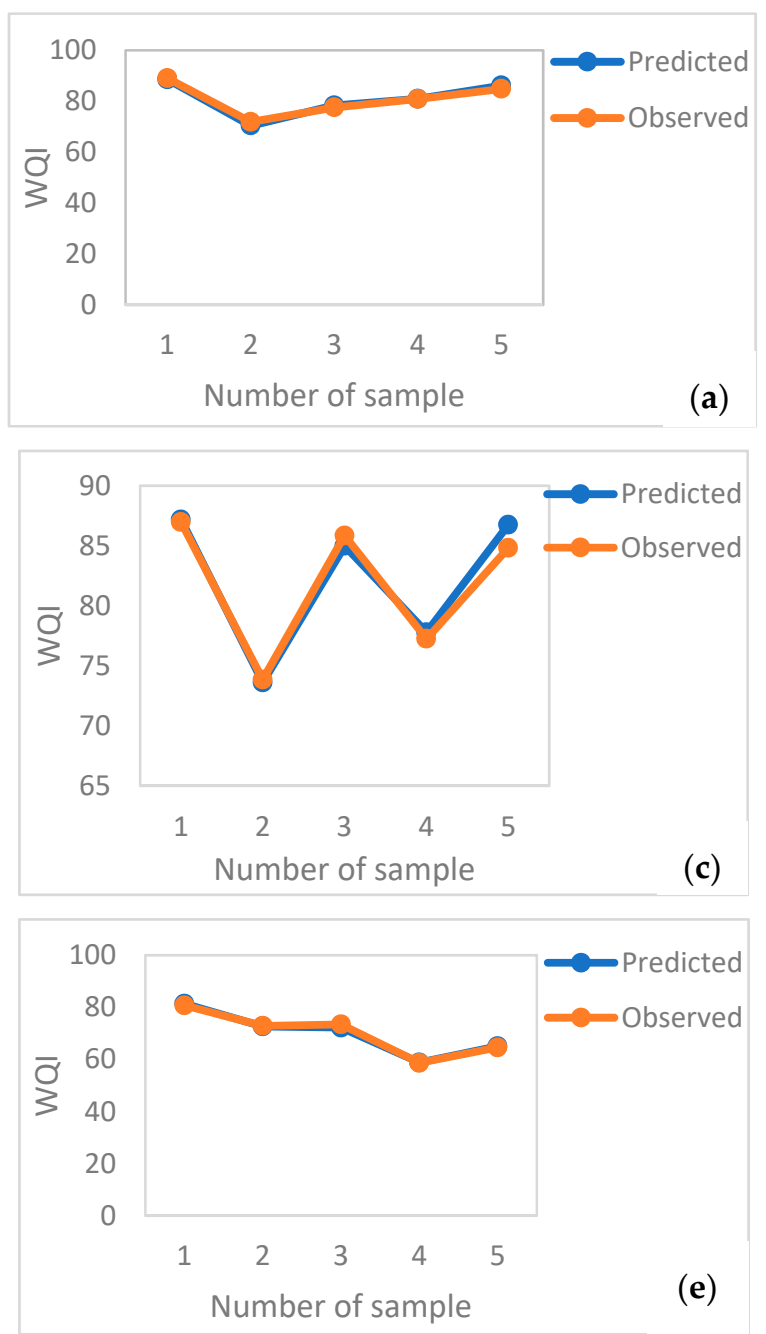
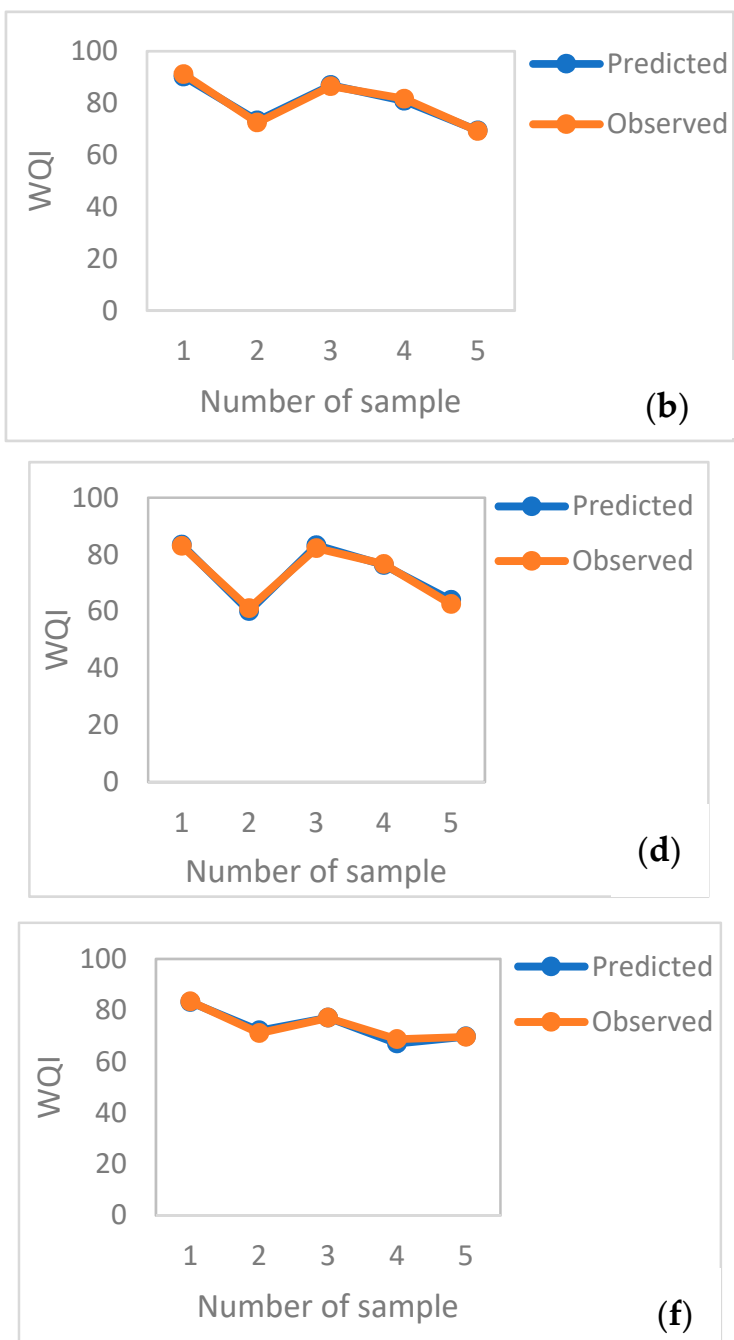

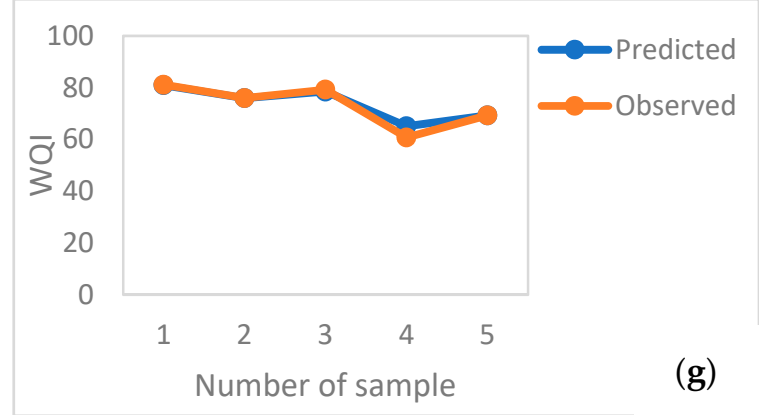

Figure 11. Series of observed and predicted WQI values during (a) upstream, (b) discharge point, (c) A, (d) B, (e) C, (f) D, and (g) E training phases in the wet season. 
(a)

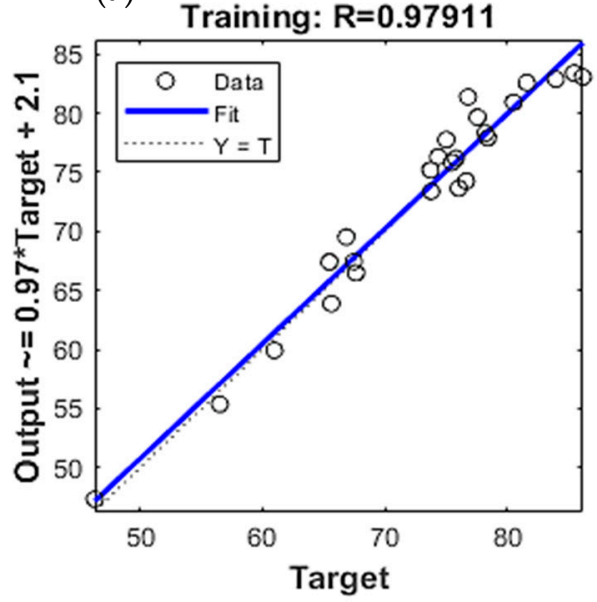

(c)

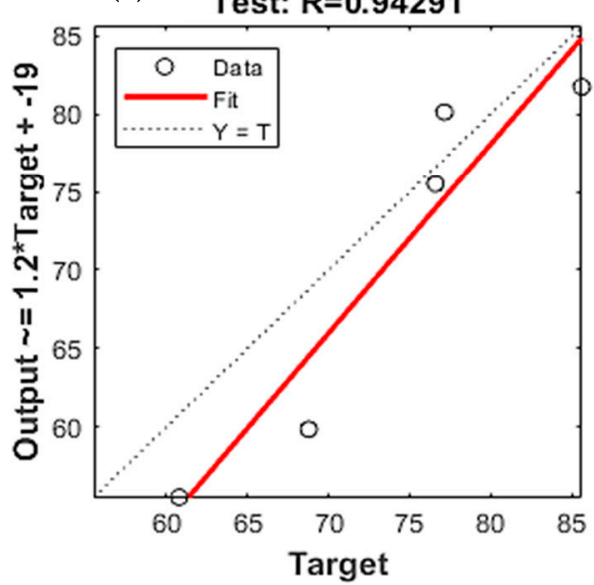

(b)

Validation: $\mathrm{R}=\mathbf{0 . 8 9 2 3 4}$

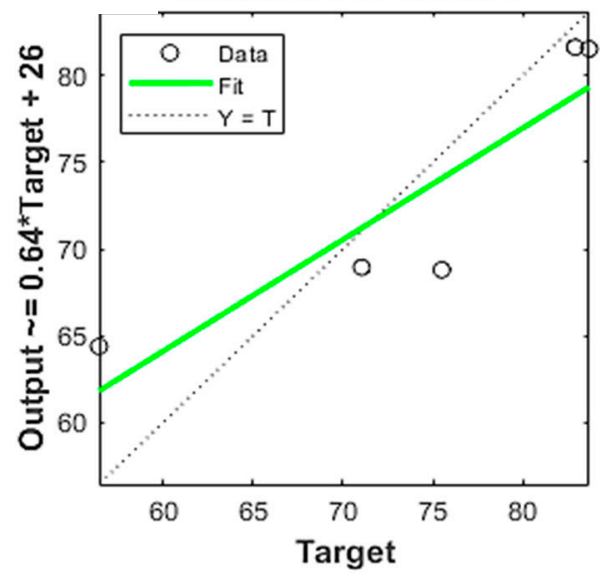

(d)

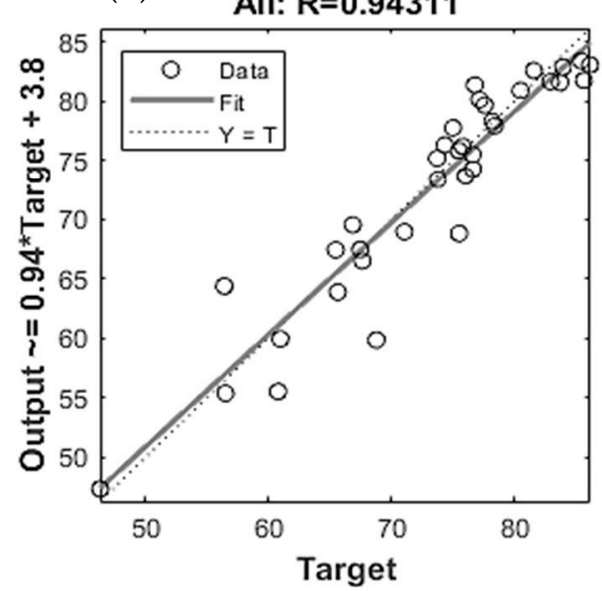

Figure 12. Comparison of predicted and observed WQI values during (a) training, (b) validation, and (c) testing phases (d) all during the dry season.

In addition, ANN was used to simulate WQI at different sampling locations, i.e., upstream, discharge point, A, B, C, D, and E during the wet and dry seasons (Figures 7 and 9). The observed WQI was in the range of 72-89, 69-91, 74-86, 61-82, 59-80, 68-83. and 61-81 in upstream, discharged point, Point A, Point B, Point C, Point D, and Point E in the wet season; and 75-85, 71-80, 75-83, 67-85, 46-78, 68-83, and 56-73 in upstream, discharge point, Point A, Point B, Point C, Point D, and Point E in the dry season. It was observed that upstream had the better water quality for both seasons compared to rest of the sampling points. Anthropogenic activities and agricultural and industrial discharges were factors that contributed to deterioration of water quality along the river. Thus, water quality for both seasons was classified as Class III.

Overall, the ANN results indicated good model performance. Finally, ANN approach utilized recorded data to develop a model that directly calculated WQI from raw data of water quality variables without the need of sub-indexing. It is direct, convenient, and believed to be a useful tool in water quality prediction. It also saves time and effort, and reduces the chance of error in calculations. 


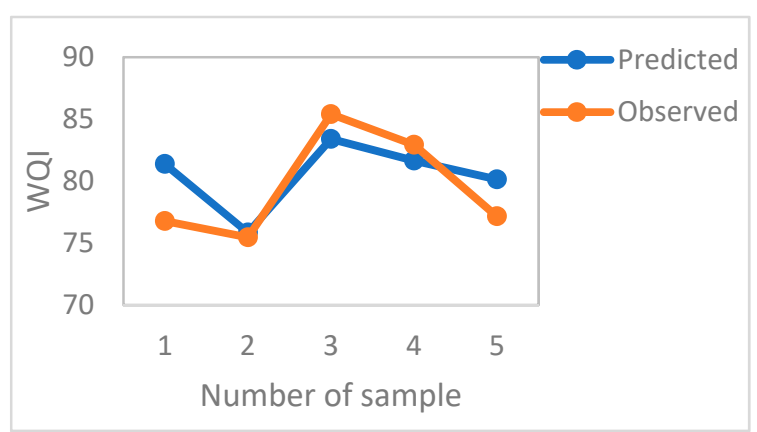

(a)

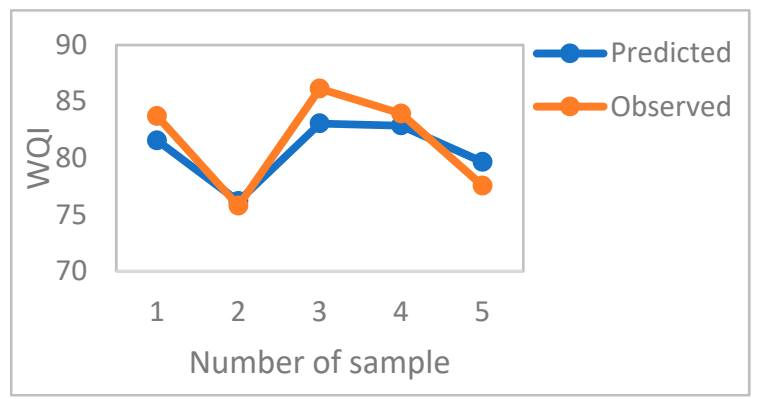

(c)

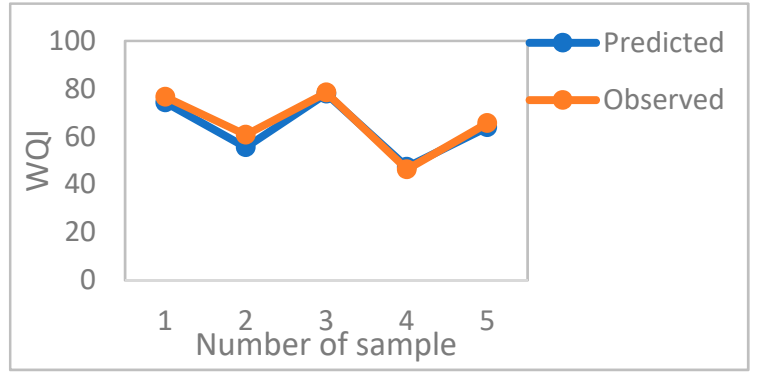

(e)

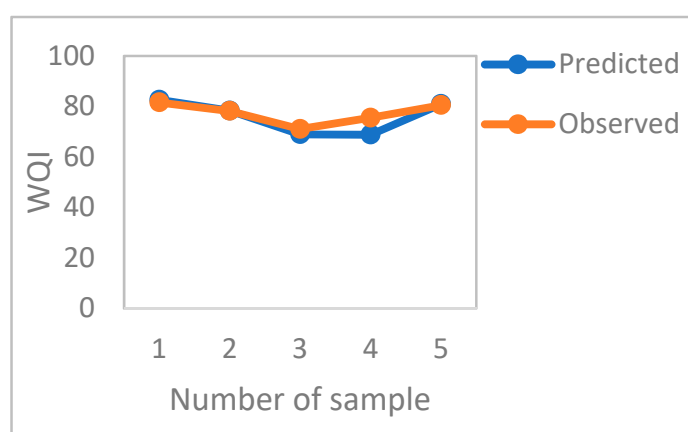

(b)

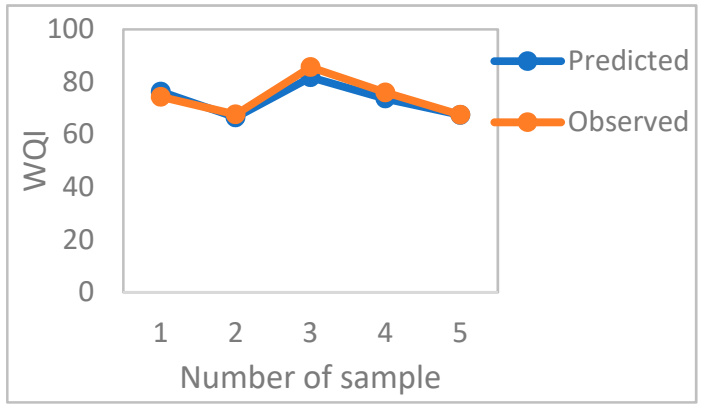

(d)

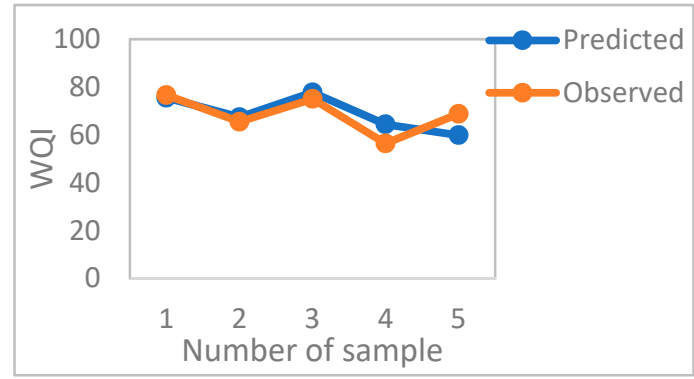

(f)

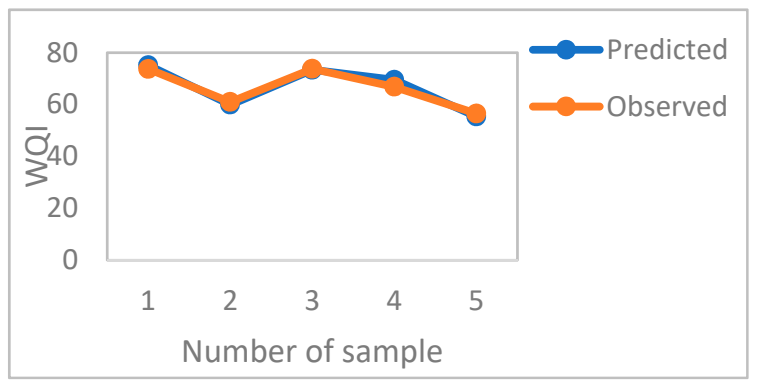

(g)

Figure 13. Series of observed and predicted WQI values during training phase (a) upstream, (b) discharge point, (c) A, (d) B, (e) C, (f) D, and (g) E in the dry season.

\subsection{TEC-ANN Modelling}

Rivers are major sources for irrigation and drinking water, and provide a habitat for aquatic organisms. However, pollutants from point and non-point sources can accumulate and cause pollution in the riverine environment. Micro-pollutants, such as polycyclic aromatic hydrocarbons (PAH), can be found in river water and are carcinogenic and toxic to the environment and human health. PAHs contamination has gained much attention in developing countries, due to increasing emission sources associated with rapid urbanization and industrial growth [43]. 
Tables 12 and 13 show the summary of input and output parameters including the minimum, maximum, mean, standard deviation, and coefficient of variation in the dry and wet season, respectively. In total, 16 priority PAHs have been chosen in this study, namely naphthalene, acenaphthylene, acenaphthene, fluorene, phenanthrene, anthracene, fluoranthene, pyrene, benzo [a] anthracene, chrysene, benzo [k] fluoranthene, benzo [b] fluoranthene, benzo [a] pyrene, dibenzo [a,h] anthraces, benzo $[\mathrm{g}, \mathrm{h}, \mathrm{i}]$ perylene, and indeno $[1,2,3 \mathrm{~cd}]$ pyrene. TEC was the output of the model.

Table 12. Summary of the input and output parameters for the dry season.

\begin{tabular}{|c|c|c|c|c|c|c|}
\hline \multirow{2}{*}{ Summary } & \multirow{2}{*}{ РAH } & \multicolumn{5}{|c|}{ Concentration (ppb) } \\
\hline & & Min & Max & Mean & SD & $\mathrm{CV}$ \\
\hline \multirow{16}{*}{ Input } & Naphthalene & 0 & 13.4 & 2.9 & 3.2 & 1.1 \\
\hline & Acenaphthylene & 0 & 10.5 & 1.6 & 2.6 & 1.6 \\
\hline & Acenaphthene & 0 & 14.8 & 2.2 & 3.0 & 1.4 \\
\hline & Fluorene & 0 & 18.7 & 1.3 & 3.0 & 2.3 \\
\hline & Phenanthrene & 0 & 109.8 & 10.7 & 23.0 & 2.1 \\
\hline & Anthracene & 0 & 66.12 & 7.1 & 15.0 & 2.1 \\
\hline & Fluoranthene & 0 & 11 & 30.3 & 76.4 & 2.5 \\
\hline & Pyrene & 0 & 364.6 & 28.5 & 72.4 & 2.5 \\
\hline & Benzo (a) anthracene & 0 & 381.2 & 20.2 & 64.0 & 3.2 \\
\hline & Chrysene & 0 & 187.2 & 11.7 & 34.1 & 2.9 \\
\hline & Benzo (b) fluoranthene & 0 & 404.1 & 26.7 & 71.3 & 2.7 \\
\hline & Benzo (k) fluoranthene & 0 & 217.5 & 18.6 & 40.8 & 2.2 \\
\hline & Benzo (a) pyrene & 0 & 354.4 & 21.0 & 55.5 & 2.6 \\
\hline & Dibenzo $(\mathrm{a}, \mathrm{h})$ anthracene & 0 & 111.8 & 5.2 & 20.1 & 3.9 \\
\hline & Indeno $(1,2,3-c d)$ pyrene & 0 & 162.6 & 5.5 & 23.2 & 4.2 \\
\hline & Benzo $(\mathrm{g}, \mathrm{h}, \mathrm{i})$ perylene & 0 & 237.0 & 11.7 & 41.5 & 3.5 \\
\hline Output & TEC & 0 & 961.7 & 54.6 & 158.0 & 2.9 \\
\hline
\end{tabular}

Table 13. Summary of the input and output parameters for the wet season.

\begin{tabular}{|c|c|c|c|c|c|c|}
\hline \multirow{2}{*}{ Summary } & \multirow{2}{*}{ PAH } & \multicolumn{5}{|c|}{ Concentration (ppb) } \\
\hline & & Min & $\operatorname{Max}$ & Mean & SD & $\mathrm{CV}$ \\
\hline \multirow{16}{*}{ Input } & Naphthalene & 0 & 13.9 & 2.3 & 3.1 & 1.3 \\
\hline & Acenaphthylene & 0 & 9.0 & 1.5 & 2.5 & 1.7 \\
\hline & Acenaphthene & 0 & 15.3 & 2.5 & 3.6 & 1.4 \\
\hline & Fluorene & 0 & 13.2 & 1.6 & 3.1 & 1.9 \\
\hline & Phenanthrene & 0 & 40.1 & 3.0 & 6.7 & 2.2 \\
\hline & Anthracene & 0 & 27.5 & 2.2 & 5.3 & 2.4 \\
\hline & Fluoranthene & 0 & 15.5 & 3.7 & 16.1 & 4.4 \\
\hline & Pyrene & 0 & 99.9 & 3.7 & 14.3 & 3.9 \\
\hline & Benzo (a) anthracene & 0 & 77.0 & 1.9 & 10.6 & 5.6 \\
\hline & Chrysene & 0 & 75.3 & 1.6 & 10.2 & 6.4 \\
\hline & Benzo (b) fluoranthene & 0 & 57.5 & 4.6 & 9.1 & 2.0 \\
\hline & Benzo (k) fluoranthene & 0 & 55.4 & 4.6 & 8.5 & 1.8 \\
\hline & Benzo (a) pyrene & 0 & 85.6 & 8.5 & 12.6 & 1.5 \\
\hline & Dibenzo $(a, h)$ anthracene & 0 & 36.6 & 1.4 & 5.0 & 3.6 \\
\hline & Indeno $(1,2,3$-cd) pyrene & 0 & 12.6 & 1.2 & 2.2 & 1.8 \\
\hline & Benzo $(\mathrm{g}, \mathrm{h}, \mathrm{i})$ perylene & 0 & 8.4 & 1.2 & 2.1 & 1.8 \\
\hline Output & TEC & 0 & 290.2 & 16.6 & 39.3 & 2.4 \\
\hline
\end{tabular}

The minimum concentration of PAHs in the dry and wet seasons was $0 \mathrm{ppb}$. Maximum concentration ranged from 10.5 to $404.1 \mathrm{ppb}$ and 8.4 to $99.9 \mathrm{ppb}$. Mean concentration ranged from 1.3 to $30.3 \mathrm{ppb}$ and 1.2 to $8.5 \mathrm{ppb}$. SD ranged from 2.6 to $76.4 \mathrm{ppb}$ and 2.5 to $16.1 \mathrm{ppb}$. Finally, CV ranged in 1.1 to $4.2 \mathrm{ppb}$ and 1.3 to $6.4 \mathrm{ppb}$, which indicates that data sets have complexity and variability 
due to non-uniformity of pollution in the sampling points. The minimum, maximum, mean, SD, and CV of the output parameter, i.e., TEC in the dry season, were $0 \mathrm{ppb}, 961.7 \mathrm{ppb}, 54.6 \mathrm{ppb}, 158.0 \mathrm{ppb}$, and $2.9 \mathrm{ppb}$. In the wet season, the values were $0 \mathrm{ppb}, 290.2 \mathrm{ppb}, 16.6 \mathrm{ppb}, 39.3 \mathrm{ppb}$, and $2.4 \mathrm{ppb}$.

TEC was calculated for ANN modelling. The data was categorized into two seasons: wet (November-March) and dry (May-September). April and October were not included as they were considered to be transition months between the wet and dry seasons. The data was divided randomly into $80 \%$ in the training set, $10 \%$ in testing, and the remaining $10 \%$ for validation. In total, 16 inputs (PAHs) and one output (TEC) were incorporated into the ANN model. The predicted outputs simulated by ANN were obtained and correlations were determined between the actual and predicted TEC values. The results are shown in Figures 14-17.
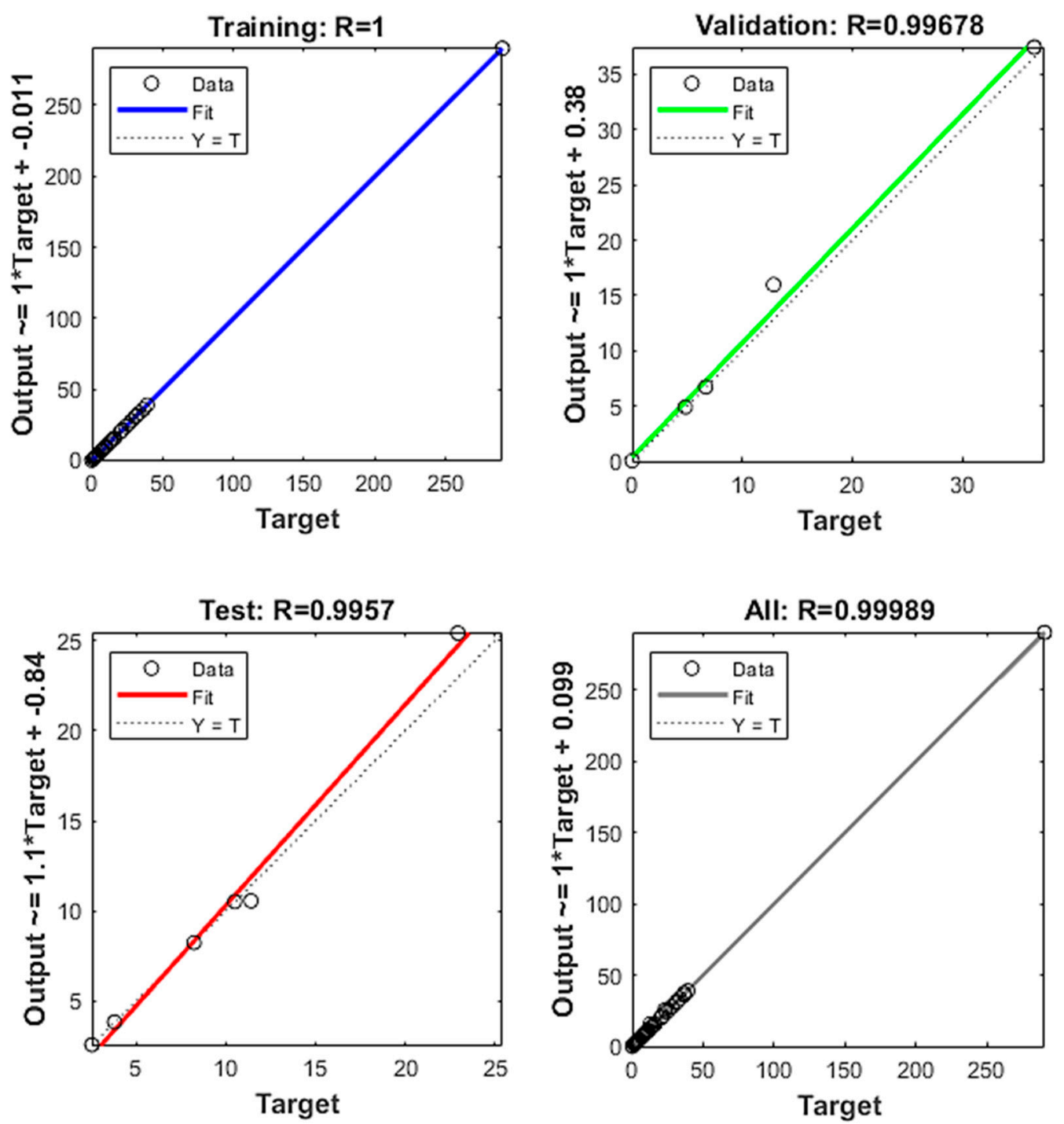

Figure 14. Comparison of the predicted and observed TEC values for training, validation, and testing phases in the wet season. 

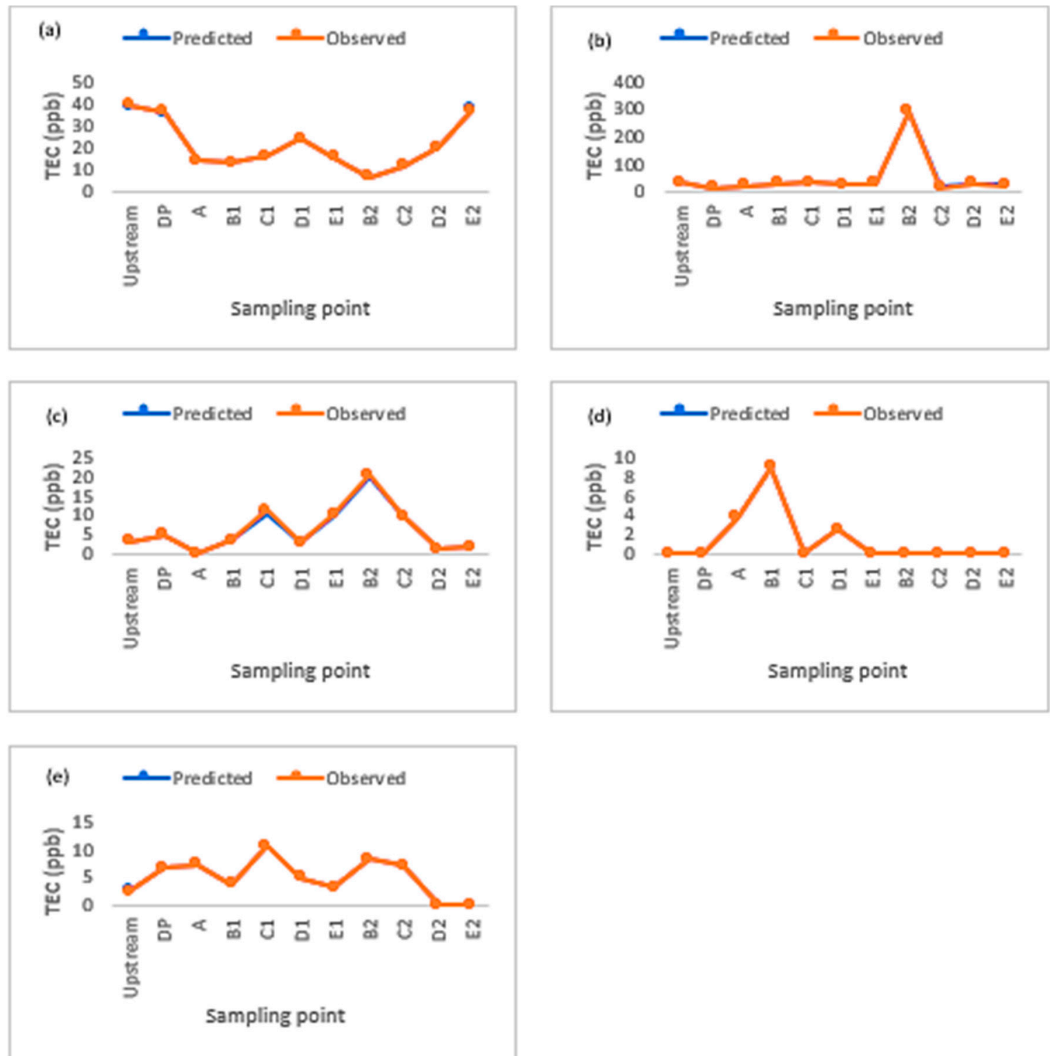

Figure 15. Series of observed and predicted TEC values (a) November, (b) December, (c) January, (d) February, and (e) March for the training phase in the wet season.
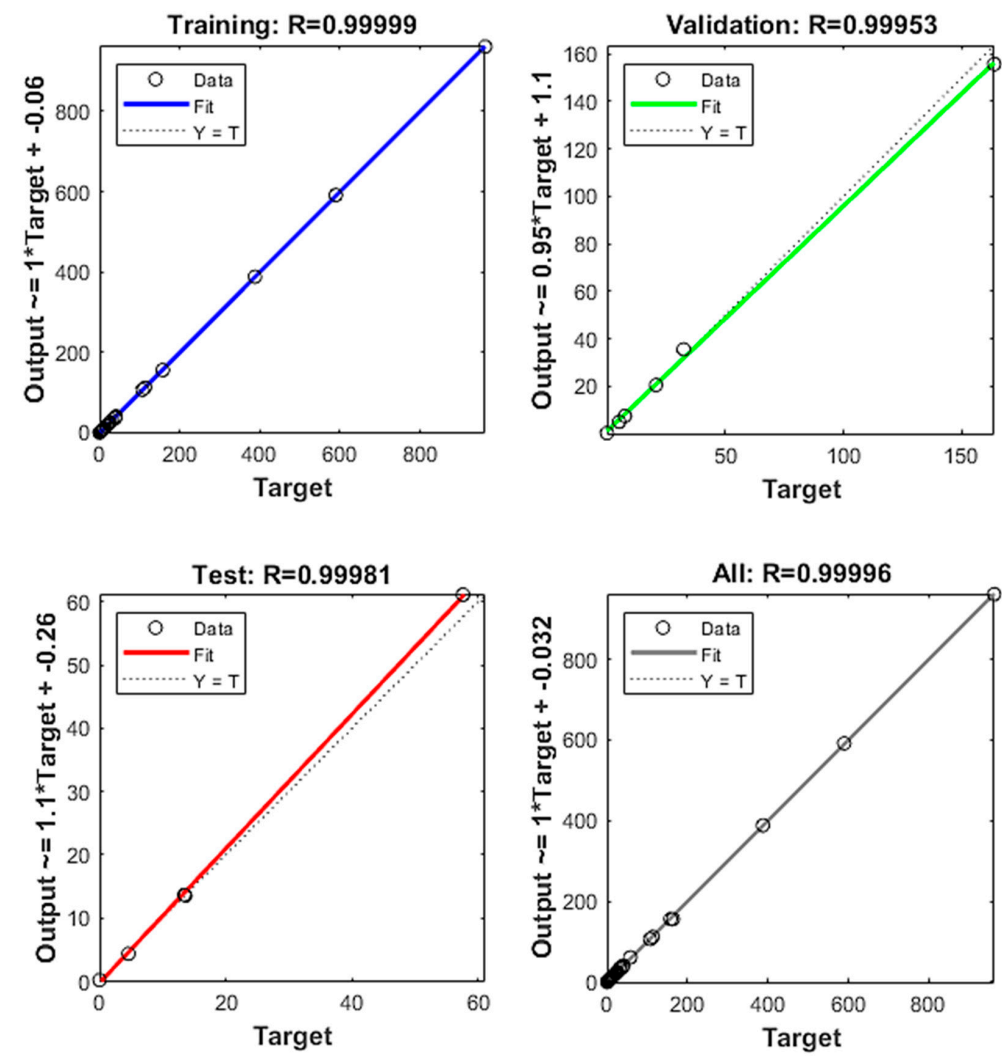

Figure 16. Comparison of predicted and observed TEC values for the training, validation, and testing phases in the dry season. 

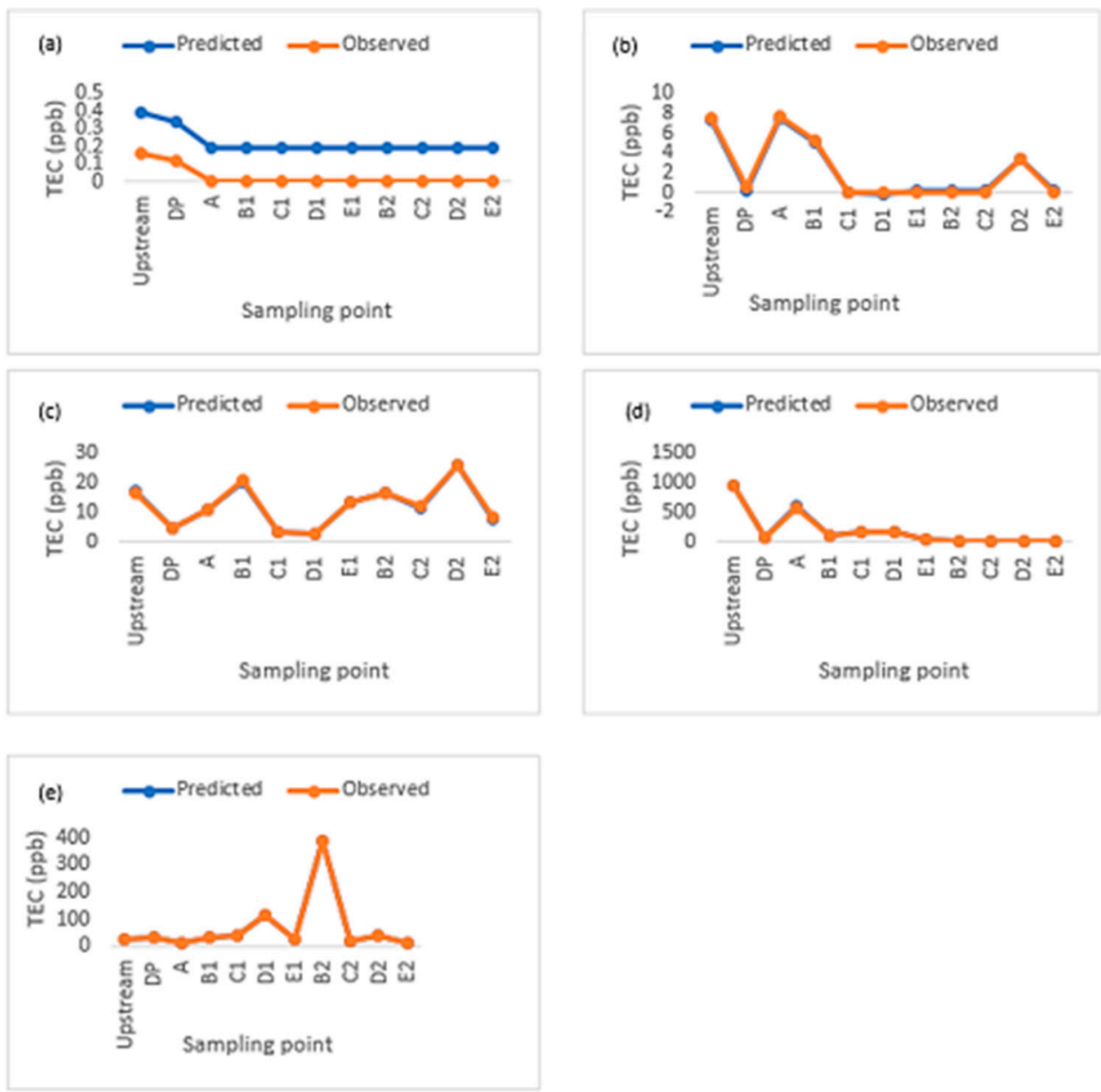

Figure 17. Monthly series of observed and predicted TEC values (a) May, (b) June, (c) July, (d) August, and (e) September for the training phase in the dry season.

TEC reflects the toxicity of PAHs relative to benzo [a] pyrene. From this study, the average TEC calculated in the wet and dry seasons was $16.6 \mathrm{ppb}$ and $54.6 \mathrm{ppb}$, respectively. TEC was higher in the dry season due to the presence of HMW weight PAH, which were more resistant to degradation and vaporization. Most TEC values decreased along the Johan River from upstream to downstream of leachate discharge (Figures 15 and 17). This was attributed to the degradation and dilution along the river. However, TEC values for both seasons were higher than the limits set by the US EPA. The allowable micro-pollutants concentration stipulated by the US EPA are $200 \mathrm{ng} / \mathrm{L}$. The TEC obtained in this study suggested that river water was not safe for consumption and could cause cancer-associated diseases.

Meanwhile, for ANN prediction, the results clearly displayed that the observed TEC values matched well with the predicted values of TEC in the training phase. $\mathrm{R}$ values for actual and predicted TEC for the wet and dry seasons are 0.9998 and 0.9999 , respectively. In this study, wet and dry seasons had $R$ values close to 1 (Tables 14 and 15), which represented a strong relationship between variables. The performance of ANN in the wet season showed MSE values of 0.0199, 1.7777, and 1.1493 in the training, validation, and testing phases, as compared to the corresponding MSE values of 0.4260 , 12.0739 , and 2.0825 during the dry season. RMSE for the wet season was 0.1411 in training, 1.3333 in validation, and 1.0721 in testing. In the dry season, it was $0.6527,3.4748$, and 1.4431 for the training, validation, and testing phases, respectively. MSE and RMSE were higher in the dry season compared to the wet season. Thus, the wet season indicated a better fit and higher prediction accuracy. Overall, the ANN results indicated good model performance. Thus, the suggested ANN approach had an 
acceptable generalization capability and accuracy in predicting impact of micropollutants on a river, and could be used as a valuable performance assessment tool for decision makers.

Table 14. Performance of the ANN model for the wet season.

\begin{tabular}{cccc}
\hline Performance & MSE & RMSE & Rp \\
\hline Training & 0.0199 & 0.1411 & 0.9999 \\
Validation & 1.7777 & 1.3333 & 0.9967 \\
Testing & 1.1493 & 1.0721 & 0.9956 \\
\hline
\end{tabular}

Table 15. Performance of the ANN model for the dry season.

\begin{tabular}{cccc}
\hline Performance & MSE & RMSE & Rp \\
\hline Training & 0.4260 & 0.6527 & 0.9999 \\
Validation & 12.0739 & 3.4748 & 0.9995 \\
Testing & 2.0825 & 1.4431 & 0.9998 \\
\hline
\end{tabular}

A few strategies can be adopted to minimize water quality concerns, particularly related to pollutants such as polycyclic aromatic hydrocarbons. PAHs are micropollutants usually found in landfill leachate, which are carcinogenic and persistent in the environment. Landfills can utilize biological treatment methods, such as activated sludge processes, sequencing batch reactors, and membrane bioreactors, to treat leachate before discharging it to a receiving river. Mojiri et al. [44] reported that lower molecular weight pollutants tend to be easily removed compared to high molecular weight pollutants because they are more likely to biodegrade/biotransform during the treatment process. Giordano et al. [45] reported that about 55\% of PAHs were removed using a sequencing batch reactor (SBR), while $0.0 \%$ to $73.5 \%$ of PAHs (mostly BghiP, NAP and PYR) were removed from wastewater using an anaerobic-anoxic-oxic treatment process. In addition, a membrane filtration system can be adopted in most industries that treat wastewater. Processes such as reverse osmosis, ultrafiltration, and nanofiltration have been shown to be able to remove PAH from aqueous solutions. Smol et al. [46] stated that removal of PAHs achieved $59 \%$ to $72 \%$ by reverse osmosis and $66.6 \%$ to $85.0 \%$ by ultrafiltration. Wang et al. [47] reported 95\% NAP removal was achieved using nanofiltration in acidic solution. Various advanced oxidation processes have also shown promise in degradation of PAHs $[10,11,44]$.

\section{Conclusions}

This study successfully showed the pattern of the water quality index and PAHs along the Johan River. Monitoring the Johan River's WQI near the Papan landfill demonstrated that the water quality ranked as Class III where intensive treatment was required prior to using the water for drinking purposes. In general, the water quality deteriorated along the river from upstream to downstream due to anthropogenic and industrial activities. Meanwhile, PAHs decreased from upstream to downstream. Notably, PAHs with higher molecular weight were dominant due to their persistent characteristic in the environment, and resistance to oxidation and vaporization. TEC values in the wet and dry seasons were $16.6 \mathrm{ppb}$ and $54.6 \mathrm{ppb}$, respectively. This indicated that the water was at high risk and not safe for consumption without adequate treatment, as it may cause cancer-associated diseases. ANN was shown to predict WQI status and TEC of the river. The results of this study indicated strong agreement between the measured and predicted outputs. Continuous assessment should be conducted in order to investigate the negative effects of PAHs in the river. The results presented in this study provide a baseline reference for future monitoring and environment protection.

Author Contributions: Conceptualization, B.T.P.J.; M.R.U.M., and M.H.I. methodology, B.T.P.J.; software, B.T.P.J.; validation, B.T.P.J.; formal analysis, B.T.P.J.; M.R.U.M., and M.H.I.; resources, M.R.U.M. and M.H.I.; data curation, B.T.P.J.; writing—original draft preparation, B.T.P.J.; writing—review and editing, B.T.P.J.; M.H.I.; A.Y. and H.Y.C.; 
supervision, M.R.U.M.; M.H.I., and H.Y.C. project administration, M.R.U.M.; and H.Y.C.; funding acquisition, M.R.U.M.; M.H.I. and H.Y.C. All authors have read and agreed to the published version of the manuscript.

Funding: This research is fully supported by a fundamental research grant scheme (FRGS), Ministry of Education (MOE) Malaysia with cost center 0153AB-L71.

Acknowledgments: The authors would like to acknowledge Universiti Teknologi PETRONAS, Ministry of Education Malaysia FRGS funding with cost center 0153AB-L71 and the support for the APC under YUTP cost center 015LC0-044. The authors appreciate Mdm. Norhayama Bt Ramli for providing technical assistance in Wastewater and Environmental Laboratory.

Conflicts of Interest: The authors declare no conflict of interest.

\section{References}

1. Zainu, Z.N.; Songip, A.H. Policies, Challenges and Strategies for Municipal Solid Waste in Malaysia. J. Sci. Technol. Innov. Policy 2017, 3, 19-22.

2. MHLG (Ministry of Housing and Local Government). Annual Report 2011(Updated to 2012). 2012. Available online: http://www.kpt.gov.my/kpkt/index.php/page/view/104 (accessed on 15 March 2019).

3. Morling, S. Landfill Leachate, Generation, Composition, and Some Findings from Leachate Treatment at Swedish Plants. Land Water Resour. Eng. 2007, 2, 172-184.

4. Jayawardhana, Y.; Kumarathilaka, P.; Herath, I.; Vithanage, M. Chapter 6-Municipal Solid Waste Biochar for Prevention of Pollution from Landfill Leachate. In Environmental Materials and Wastes Resource Recovery and Pollution Prevention; National Institute of Fundamental Studies: Kandy, Sri Lanka, 2016; pp. 117-148.

5. Foul, A.A.; Aziz, H.A.; Isa, M.H.; Hung, Y.T. Primary Treatment of Anaerobic Landfill Leachate Using Activated Carbon and Limestone: Batch and Column Studies. Int. J. Environ. Waste Manag. 2009, 4, 282. [CrossRef]

6. Yusof, N.; Haraguchi, A.; Hassan, M.A.; Othman, M.R.; Wakisaka, M.; Shirai, Y. Measuring Organic Carbon, Nutrients and Heavy Metals in Rivers Receiving Leachate from Controlled and Uncontrolled Municipal Solid Waste (MSW) Landfills. Waste Manag. 2009, 29, 2666-2680. [CrossRef] [PubMed]

7. DOE 2008. Malaysia Environmental Quality Report; Department of Environment, Ministry of Natural Resources and Environment: Kuala Lumpur, Malaysia, 2008; p. 86.

8. Wu, Z.; Wang, X.; Chen, Y.; Cai, Y.; Deng, J. Assessing River Water Quality Using Water Quality Index in Lake Taihu Basin, China. Sci. Total. Environ. 2018, 612, 914-922. [CrossRef] [PubMed]

9. Binayani, B.; Satapathy, D.P. Application of Artificial Neural Network to Predict the Water Quality Index of Brahmani River Basin Odisha, India. Int. J. Emerg. Res. Manag. Technol. 2017, 6, 2278-9359.

10. Yaqub, A.; Isa, M.H.; Kutty, S.R.M.; Ajab, H. Electrochemical Degradation of PAHs in Produced Water Using Ti/Sb2O5-SnO2-IrO2 Anode. Electrochemistry 2014, 82, 979-984. [CrossRef]

11. Yaqub, A.; Isa, M.H.; Ajab, H. Electrochemical Degradation of Polycyclic Aromatic Hydrocarbons in Synthetic Solution and Produced Water Using a Ti/SnO2-Sb2O5-RuO2 Anode. J. Environ. Eng. 2015, 141, 04014074. [CrossRef]

12. Baali, A.; Yahyaoui, A. Polycyclic Aromatic Hydrocarbons (PAHs) and Their Influence to Some Aquatic Species. Intech Open. Available online: https://www.intechopen.com/online-first/polycyclic-aromatichydrocarbons-pahs-and-their-influence-to-some-aquatic-species (accessed on 13 August 2020).

13. Rojas, N.Y.; Milquez, H.A.; Sarmiento, H. Characterizing Priority Polycyclic Aromatic Hydrocarbons (PAH) in Particulate Matter from Diesel and Palm Oil-Based Biodiesel B15 Combustion. Atmos. Environ. 2011, 45, 6158-6162. [CrossRef]

14. Nisbet, I.; Lagoy, P. Toxic Equivalency Factors (TEFs) for Polycyclic Aromatic Hydrocarbons (PAHs). Regul. Toxicol. Pharmacol. 1992, 16, 290. [CrossRef]

15. Pakpahan, E.N.; Isa, M.H.; Kutty, S.R.M.; Chantara, S.; Wiriya, W. Polycyclic Aromatic Hydrocarbon Removal from Petroleum Sludge Cake Using Thermal Treatment with Additives. Environ. Technol. 2013, 34, 407-416. [CrossRef] [PubMed]

16. Gazzaz, N.M.; Yusoff, M.K.; Aris, A.Z.; Juahir, H.; Ramli, M.F. Artificial Neural Network Modeling of the Water Quality Index for Kinta River (Malaysia) Using Waterquality Variables as Predictors. Mar. Pollut. Bull. 2012, 64, 2409-2420. [CrossRef] [PubMed] 
17. New Straith Time. New Cell Opens at landfill. 2014. Available online: https://www.nst.com.my/news/2015/ 09/new-cell-opens-landfill (accessed on 19 July 2019).

18. Malaysia Map. Available online: https://www.malaysiavacationguide.com/malaysiamap.html (accessed on 13 August 2020).

19. APHA. Standard Methods for the Examination of Water and Wastewater, 21st ed.; American Public Health Association/American Water Works Association/Water Environment Federation: Washington, DC, USA, 2005.

20. Mustafa, M.R.; Rezaur, R.B.; Saiedi, S.; Rahardjo, H.; Isa, M.H. Evaluation of MLP-ANN Training Algorithms for Modeling Soil Pore-Water Pressure Responses to Rainfall. J. Hydrol. Eng. 2013, 18, 50-57. [CrossRef]

21. Ranković, V.; Radulović, J.; Radojević, I.; Ostojić, A.; Čomić, L. Neural Network Modelling of Dissolved Oxygen in the Gruža Reservoir. Serb. Ecol. Model. 2010, 221, 1239-1244. [CrossRef]

22. Ruben, G.B.; Zhang, K.; Bao, H.; Ma, X. Application and Sensitivity Analysis of Artificial Neural Network for Prediction of Chemical Oxygen Demand. Water Resour. Manag. 2018, 32, 273-283. [CrossRef]

23. Mustafa, M.R.U.; Bhuiyan, R.R.; Isa, M.H.; Saiedi, S.; Rahardjo, H. Effect of Antecedent Conditions on Prediction of Pore Water Pressure Using Artificial Neural Networks. Mod. Appl. Sci. 2012, 6, 6-15. [CrossRef]

24. Khaki, M.; Yusoff, I.; Islami, N.; Hussin, H. Artificial Neural Network Technique for Modeling of Groundwater Level in Langat Basin, Malaysia. Sains Malays. 2016, 45, 19-28.

25. Mustafa, M.R.; Rezaur, R.B.; Saiedi, S.; Isa, M.H. River Suspended Sediment Prediction Using Various Multilayer Perceptron Neural Network Training Algorithms-A Case Study in Malaysia. Water Resour. Manag. 2012, 26, 1879-1897. [CrossRef]

26. Zazoulif, M.A.; Maleki, A.; Izanloo, H. Assessment of Raw Leachate Characteristics and Its Pre-treatment by Lime. Asian J. Chem. 2010, 22, 6155-6163.

27. Yilmaz, T.; Aygün, A.; Berktay, A.; Nas, B. Removal of COD and Colour from Young Municipal Landfill Leachate by Fenton Process. Environ. Technol. 2010, 31, 1635-1640. [CrossRef]

28. Jumaah, M.A.; Othman, M.R.; Yusop, M.R. Characterization of Leachate from Jeram Sanitary Landfill-Malaysia. Int. J. Chem. Tech. Res. 2016, 9, 571-574.

29. Aziz, H.A.; Ramli, S.F. Recent Development in Sanitary Landfilling and Landfill Leachate Treatment in Malaysia. Int. J. Environ. Eng. 2018, 9, 201-229. [CrossRef]

30. Mohd, R.F.; Tahir, W.; Yahaya, N.K.E. Studies on the Current State of Water Quality in the Segamat River. IOP Conf. Ser. Earth Environ. Sci. 2018, 140, 12-16.

31. Alssgeer, H.; Gasim, M.; Hanafiah, M.; Abdulhadi, E.; Azid, A. GIS-based Analysis of Water Quality Deterioration in the Nerus River, Kuala Terengganu, Malaysia. Desalin. Water Treat. 2018, 112, 334-343. [CrossRef]

32. Hasan, H.H.; Jamil, N.R.; Aini, N. Water Quality Index and Sediment Loading Analysis in Pelus River, Perak, Malaysia. Procedia Environ. Sci. 2015, 30, 133-138. [CrossRef]

33. Jiries, A.; Rimawi, O.; Lintelmann, J.; Batarseh, M. Polycyclic Aromatic Hydrocarbons (PAH) in Topsoil, Leachate and Groundwater from Ruseifa Solid Waste Landfill, Jordan. Int. J. Environ. Pollut. 2005, 23, 179. [CrossRef]

34. Zdanevitch, I.; Bour, O.; Lejal, S.; Briand, M. Measurement of Persistent Organic Pollutants in Landfill Leachates 14; International Waste Management and Landfill Symposium: Sardinia, Cagliari, Italy, 2013; NC. ffineris-00976247f.

35. Edokpayi, J.; Odiyo, J.; Popoola, O.; Msagati, T. Determination and Distribution of Polycyclic Aromatic Hydrocarbons in Rivers, Sediments and Wastewater Effluents in Vhembe District, South Africa. Int. J. Environ. Res. Public Health 2016, 13, 387. [CrossRef]

36. Tałałaj, I.A.; Biedka, P.; Walery, M.J.; Leszczyński, J. Monitoring of Leachate Quality at A Selected Municipal Landfill in Poland. J. Ecol. Eng. 2016, 17, 175-184. [CrossRef]

37. Chen, Y.; Sun, C.; Zhang, J.; Zhang, F. Assessing 16 Polycyclic Aromatic Hydrocarbons (PAHs) in River Basin Water and Sediment Regarding Spatial-Temporal Distribution, Partitioning, and Ecological Risks. Pol. J. Environ. Stud. 2018, 27, 579-589. [CrossRef]

38. Kim, D.; Young, T.M. Significance of Indirect Deposition on Wintertime PAH Concentrations in An Urban Northern California Creek. Environ. Eng. Sci. 2009, 26, 269-278. [CrossRef] 
39. Li, J.; Shang, X.; Zhao, Z.; Tanguay, R.L.; Dong, Q.; Huang, C. Polycyclic Aromatic Hydrocarbons in Water, Sediment, Soil, and Plants of the Aojiang River Waterway in Wenzhou, China. J. Hazard. Mater. 2010, 173, 75-81. [CrossRef] [PubMed]

40. Adeniji, A.O.; Okoh, O.O.; Okoh, A.I. Levels of Polycyclic Aromatic Hydrocarbons in the Water and Sediment of Buffalo River Estuary, South Africa and Their Health Risk Assessment. Arch. Environ. Contam. Toxicol. 2019, 76, 657-669. [CrossRef] [PubMed]

41. Igwe, J.C.; Ukaogo, P.O. Environmental Effects of Polycyclic Aromatic Hydrocarbons. J. Nat. Sci. Res. 2015, 5, 2224-3186.

42. Pashin, Y.V.; Bakhitova, L.M. Mutagenic and Carcinogenic Properties of Polycyclic Aromatic Hydrocarbons. Environ. Health Perspect. 1979, 30, 185-189. [CrossRef]

43. Lang, C.; Tao, S.; Liu, W.; Zhang, Y.; Simonich, S. Atmospheric Transport and Outflow of Polycyclic Aromatic Hydrocarbons from China. Environ. Sci. Technol. 2008, 42, 5196-5201. [CrossRef]

44. Mojiri, A.; Zhou, J.L.; Ohashi, A.; Ozaki, N.; Kindaichi, T. Comprehensive Review of Polycyclic Aromatic Hydrocarbons in Water Sources, Their Effects and Treatments. Sci. Total Environ. 2019, 696, 133971. [CrossRef]

45. Giordano, A.; Stante, L.; Pirozzi, F.; Cesaro, R.; Borotone, G. Sequencing Batch Reactor Performance Treating PAH Contaminated Lagoon Sediments. J. Hazard. Mater. 2005, 119, 159-166. [CrossRef]

46. Smol, M.; Włodarczyk, M. Effectiveness in the Removal of Polycyclic Aromatic Hydrocarbons from Industrial Wastewater by Ultrafiltration Technique. Arch. Environ. Prot. 2012, 38, 49-58. [CrossRef]

47. Wang, X.D.; Zhang, H.H.; Wang, L.; Guo, X.F. Study of effects of ionic strength and pH on PAHs removal by nanofiltration. In Proceedings of the 2nd Annual Congress on Advanced Engineering and Technology II (CAET 2015), Hong Kong, China, 4-5 April 2015; Xie, L., Ed.; CRC Press: Boca Raton, FL, USA, 2015.

(C) 2020 by the authors. Licensee MDPI, Basel, Switzerland. This article is an open access article distributed under the terms and conditions of the Creative Commons Attribution (CC BY) license (http://creativecommons.org/licenses/by/4.0/). 